Article

\title{
Lessons from Remarkable FinTech Companies for the Financial Inclusion in Peru
}

\author{
Patricia Vilcanqui Velazquez ${ }^{1}$, Vito Bobek ${ }^{1, *(D)}$, Romana Korez Vide ${ }^{2}$ and Tatjana Horvat ${ }^{3}$ \\ 1 Institute of International Management, University of Applied Sciences FH Joanneum, 8020 Graz, Austria; \\ patricia.vilcanquivelazquez@edu.fh-joanneum.at \\ 2 Faculty of Economics and Business, University of Maribor, 2000 Maribor, Slovenia; romana.korez@um.si \\ 3 Faculty of Management, University of Primorska, 6101 Koper, Slovenia; tatjana.horvat@fm-kp.si \\ * Correspondence: vito.bobek@fh-joanneum.at; Tel.: +43-316-5453-6829
}

check for

updates

Citation: Velazquez, Patricia

Vilcanqui, Vito Bobek, Romana Korez

Vide, and Tatjana Horvat. 2022.

Lessons from Remarkable FinTech

Companies for the Financial

Inclusion in Peru. Journal of Risk and

Financial Management 15: 62.

https://doi.org/10.3390/jrfm

15020062

Academic Editor: Anica Hunjet

Received: 6 December 2021

Accepted: 25 January 2022

Published: 30 January 2022

Publisher's Note: MDPI stays neutral with regard to jurisdictional claims in published maps and institutional affiliations.

Copyright: (C) 2022 by the authors. Licensee MDPI, Basel, Switzerland. This article is an open access article distributed under the terms and conditions of the Creative Commons Attribution (CC BY) license (https:// creativecommons.org/licenses/by/ $4.0 /)$.

\begin{abstract}
Financial inclusion, defined as the adequate access and usage of formal financial services to improve people's lives, is a crucial area for the economic development of a country through its various angles. This paper analyzes the impact of selected FinTech companies on financial inclusion in their respective countries to obtain lessons of their business models and country environments that can help Peruvian financial inclusion. The selected FinTechs are M-PESA in Kenya, Nubank in Brazil, GCASH in the Philippines, and Easypaisa in Pakistan, which revolutionized the financial sector in their respective countries. However, a comparative study of their impact on financial inclusion in their respective country has not been conducted yet; therefore, the lessons obtained are helpful for the Peruvian situation due to their practical implications and because they raise possible areas for further and deeper research. The approach of this study considered a qualitative and quantitative method (to find a Pearson correlation between the percentage of the population of Country (A) that are users of FinTech (a) and the six selected demand-side indicators per country retrieved from the Global Findex Database) analysis to understand the results obtained. The results obtained indicate that M-PESA and GCASH, companies specialized in providing basic mobile money transactions such as remittances and withdrawals, did not impact the provision of other financial services such as savings or credit cards. In Easypaisa's case, this company positively impacts the studied indicators, probably due to its original partnership with a microfinance institution. Regarding Nubank, despite its remarkable growth in the last years, the company does not affect financial inclusion in Brazil yet. Nonetheless, after its recent expansion to provide more financial services, future research could assess the impact of this company on Brazilian financial inclusion.
\end{abstract}

Keywords: FinTech's; Nubank; M-PESA; GCASH; Easypaisa; financial inclusion; mobile money; remittances emerging markets; international business; business economics

\section{Introduction}

This paper aims to study selected indicators of remarkable Fintech companies in Kenya, Brazil, Pakistan, and the Philippines to gain valuable lessons for financial inclusion in Peru. This goal will be achieved through a deep but summarized understanding of the definition, importance, and determinants of financial inclusion and the causes of financial exclusion.

Despite the importance of financial inclusion, there is no consensus about its definition and measurement (Nguyen 2020). Therefore, a straightforward approach in this study cannot be made without first understanding the primary and minimum concepts regarding financial inclusion.

After a basic literature review, this study aims to provide solid and consistent evidence of the benefits of financial inclusion for people and many reasons people are financially excluded. Among these reasons include geographical difficulties or physical access, the 
lack of proper documentation such as, for example, identification purposes, and the high prices or fees of financial services, which discourage low-income people from access to financial services (Stein et al. 2011).

The reasons and causes of financial exclusion are essential for this study because the problem can be understood, addressed, and treated as a market failure that requires considering supply and demand factors. From the demand side, there is a broad consensus that people from less developed countries are less financially included, whereas people from developed countries are more financially included (Atkinson and Messy 2013; Rojas-Suarez and Gonzales 2010).

From the supply side, recent evidence proves that mobile money accounts provided mainly by Fintechs have been gaining users in developing countries, facilitating financial transactions, expanding to other financial services, and improving financial education (Nguyen 2020; Damodaran 2013).

The following step in this research includes analyzing the environmental context of Peru and comparing it to countries that have started early in mobile money accounts and have designed and applied financial inclusion strategies at the national or subnational levels (Pearce and Ortega 2012). This section will gather data regarding each country's environment, demand, and supply sides, and on the supply side, the remarkable FinTechs will be presented. FinTech is a new concept referred to as a technology-enabler innovation in financial services, rapidly expanding in developing countries and improving financial inclusion indicators (Nguyen 2020; Pearce and Ortega 2012). The selected FinTechs are M-PESA from Kenya, Nubank from Brazil, G-Cash from the Philippines, and Easypaisa from Pakistan.

\section{Problem Statement}

In June 2021, BBC News (2021), The Guardian (2021), BMJ (2021), and many other media published that Peru has the highest COVID-19 death rate globally according to the government's review and update of the information related to COVID-19-related deaths. According to this updated information, more than $0.5 \%$ of Peruvians died from this disease. A dramatic toll was worse than that recorded by the UK during the Spanish influenza pandemic in 1918-20 (BMJ 2021).

The question is why Peru was so severely hit during this pandemic, despite the imposition of one of the earliest and strictest lockdowns, faster testing, and personal liberty rights restrictions in Latin America. The press explained that the main reasons for this severe impact of the pandemic in Peru were the widespread poverty, largely informal economy, crowded houses, only $38 \%$ of Peruvians having bank accounts, the fragile and unprepared health system, and the slower vaccination process (BBC News 2021; BMJ 2021). However, a fact that is not related to the disease-government social aids directed to help people who lost their jobs or the most vulnerable and poorer population-is that individuals could not receive economic support from the government because most adult Peruvians do not own a bank account, making digital payments impossible (BBC News 2021). CGAP briefing guides those designing and deploying social assistance payments to help them work with financial sector regulators and implement social assistance payments that facilitate rapid, remote account opening in compliance with anti-money laundering and counter-financing of terrorism (AML/CFT) rules (Economist Intelligence Unit 2020). The Peruvian government adopted a financial inclusion strategy. However, it was also found that this country has a weak adherence to the law. Therefore, from a regulatory perspective, the incentives to the supply and demand side are probably not optimal. For example, it could be the case that the regulation to acquire the respective permissions is too strict. This topic could be further analyzed from a specific legal perspective.

The natural consequence of this situation is that many people were forced to agglomerate at bank offices, lining up to receive their emergency government aid in cash, facilitating the virus transmission, chaos, and distrust among the population. Afterward, in October of 2020, an important bank in Peru and the government recognized that the containment of the 
virus would have been more efficient if this country had higher rates of financial inclusion and financial education. Therefore, in the Peruvian case, financial inclusion does not only help people to improve their lifestyle, but it also may save lives when the government aims to provide social aid or distribute wealth.

In recent years, researchers and international organizations recognized several remarkable FinTechs disrupting the banking sector by taking a leading role in many financial services such as mobile money and mobile banking. For this reason, it is worthy of analyzing these companies in their respective country to learn lessons that can contribute to financial inclusion in Peru.

This analysis will be made by considering that these companies are part of a financial system that requires close contact with the government to prevent the collapse of these companies that promote financial inclusion (Omar and Inaba 2020). Therefore, a broad comprehension of the context of each country will guide the solution of the problem statement.

This paper aims to analyze the overall situation of financial inclusion in five different countries that have implemented a successful financial inclusion strategy that improved the access and usage of financial services among their population. After collecting data from the environment, demand, and supply side, the empirical analysis will be conducted with qualitative and quantitative analysis. The qualitative part consists of benchmarking that compares business-related qualitative information of the selected FinTechs to understand each company's business model. The quantitative part consists of a multivariable correlation analysis between demand and supply-side indicators. The information gathered about the environmental side will explain the results. The empirical research will provide insights into determining events, business strategy, and the overall environment required by Peru to improve financial inclusion.

There is abundant literature regarding methods of measuring financial inclusion. Among these studies, the World Bank, IMF, the BBVA Bank, and many other institutions tried to measure financial inclusion per country and consider various indicators. All studies conclude the significant relationship between lower financial inclusion rates with poverty and income inequality in emerging countries (Barajas et al. 2020). During the COVID19 crisis, a survey of the trends and drivers of financial inclusion was also developed, considering the current context to guide policymakers seeking to design strategies for their respective countries (Sotomayor et al. 2018). However, this research did not include a case study analysis of FinTechs nor a country study analysis.

There is no comparative study on remarkable FinTechs disrupting or improving financial inclusion in their respective countries that offers lessons for financial inclusion in a specific country. Therefore, this study would be constructive for understanding remarkable FinTechs' business models and learning lessons for financial inclusion in Peru, a country with lower financial inclusion indicators. A summarized overview of Peru is presented in Table 1.

The definition of financial inclusion adopted by the Peruvian government is the access to and use of financial services with quality for all population segments. The access dimension is understood as the possibility of contracting products and services offered by the financial sector. The use dimension refers to the practical, frequent, and sustainable acquisition and use of financial products or services (Sotomayor et al. 2018).

A synthesized diagnosis of the Peruvian context of financial inclusion can be made by considering demand-side indicators provided by the Global Findex Database for 2011, 2014, and 2017 (Demirgüç-Kunt et al. 2018). It is shown in Table 2.

There are many reasons why financial inclusion in Peru is very low. According to Sotomayor et al. (Sotomayor et al. 2018), the proximity of the access points to the population shows that it affects the usage of bank accounts and credits because of the time of transportation to the access point for making transactions. Therefore, the probability of obtaining informal credits is higher. 
Table 1. Country overview-Peru.

\begin{tabular}{|c|c|}
\hline Characteristic & Situation \\
\hline $\begin{array}{l}\text { Geographical conditions and } \\
\text { population distribution }\end{array}$ & $\begin{array}{l}\text { Peru has a western coastal plain (costa), high and rugged Andes } \\
\text { in the center (Sierra), eastern lowland jungle of Amazon Basin } \\
\text { (Jungle). Area: } 496,225 \text { sq. miles. Approximately one-third of the } \\
\text { population lives along the desert coastal, focusing on Lima's } \\
\text { capital city. The remote cities in the Andean highlands, the } \\
\text { rainforests, and the jungle are sparsely populated (CIA.gov } \\
\text { 2021d). }\end{array}$ \\
\hline Population & $\begin{array}{l}\text { The adult population in Peru (ages } 15 \text { to } 64 \text { ) in } 2020 \text { was roughly } \\
10.9 \text { million. } \\
\text { In } 2011,2014 \text {, and } 2017 \text { the population was } 9.2,9.6 \text {, and } 10.3 \\
\text { million inhabitants, respectively (World Bank 2020b). }\end{array}$ \\
\hline Mobile phone penetration & $\begin{array}{l}\text { By 2019, the subscriptions per } 100 \text { inhabitants were } 123.76 \\
\text { (CIA.gov 2021d). }\end{array}$ \\
\hline The rule of law & $\begin{array}{l}\text { According to the Rule of Law index, Peru is ranked in the } 80 \text { th } \\
\text { position out of } 128 \text { countries, and its score is } 0.5 \text {, which means law } \\
\text { enforcement and institutions are weak and there are corruption } \\
\text { problems in the government (The World Justice Project 2020). }\end{array}$ \\
\hline Financial literacy & $\begin{array}{l}\text { In } 2015 \text {, a survey found that } 28 \% \text { of the Peruvian population was } \\
\text { financially literate (The World Justice Project 2020). }\end{array}$ \\
\hline Banking concentration & $\begin{array}{l}\text { In 2017, } 72 \% \text { of the market was concentrated in a few banks } \\
\text { (World Bank 2021b). }\end{array}$ \\
\hline Multiculturality & $\begin{array}{l}\text { Ethnic groups: mixed Amerindian and white }(60.2 \%) \text {, } \\
\text { Amerindians (25.8\%), White (5.9\%), African descent (3.6\%), } \\
\text { Chinese and Japanese descent }(1.2 \%) \text {, and unspecified (3.3\%) } \\
\text { (CIA.gov 2021d). } \\
\text { Official Languages: Spanish ( } 82.9 \%) \text {, Quechua }(13.6 \%) \text {, Aymara } \\
(1.6 \%) \text {, Ashaninka } 0.3 \% \text {, and others (CIA.gov 2021d). }\end{array}$ \\
\hline $\begin{array}{l}\text { Employment to population } \\
\text { ratio }\end{array}$ & $\begin{array}{l}\text { In 2019, the pre-pandemic year, the employment rate in Peru was } \\
75.5 \% \text { (World Bank 2021b). }\end{array}$ \\
\hline $\begin{array}{l}\text { Gross National Income per } \\
\text { capita }\end{array}$ & In 2020, the GNI per capita was USD 6010 (World Bank 2021b). \\
\hline
\end{tabular}

Table 2. Selected indicators regarding financial inclusion in Peru.

\begin{tabular}{cccc}
\hline Indicator & $\mathbf{2 0 1 1}$ & $\mathbf{2 0 1 4}$ & $\mathbf{2 0 1 7}$ \\
\hline Account ownership (\% age 15+): & $20 \%$ & $29 \%$ & $43 \%$ \\
Mobile money account (\% age 15+) & - & $0 \%$ & $3 \%$ \\
Sent or received domestic remittances through a & - & $0 \%$ & $2 \%$ \\
mobile phone (\% age 15+) & $10 \%$ & $12 \%$ & $12 \%$ \\
Credit card ownership (\% age 15+) & $14 \%$ & $21 \%$ & $28 \%$ \\
Debit card ownership (\% age 15+) & $9 \%$ & $12 \%$ & $8 \%$ \\
Saved at a Financial Institution (\% age 15+) & & & \\
\hline
\end{tabular}

Source: Own illustration based on the Global Findex Database (Demirgüç-Kunt et al. 2018).

Regarding mobile money accounts, the increase from 0 in 2014 to 3\% in 2017 could be attributed to the launch of BIM in 2016, a mobile wallet service created by Asbanc (Association of Peruvian banks-Asociación de Bancos del Peru) and Ericson with the purpose to connect unbanked individuals to the formal financial system. Therefore, after 2016 it was foreseen that FinTech companies play an increasing role in financial inclusion in this country (Economist Intelligence Unit 2019).

According to the analysis of the Global Microscope (Economist Intelligence Unit 2019), with an overall financial score after assessing the enabling environment for financial 
inclusion, Peru achieves a high overall financial inclusion score (82/100), surpassing peer countries in Latin America and the Caribbean and upper-middle-income countries due to government support, market stability and integrity, excellent products and outlets, and better quality consumer protection rules and infrastructure.

\section{Literature Review}

This section will develop a deep but summarized presentation of fundamental concepts on Financial inclusion. These basic concepts include an updated definition of Financial inclusion; the causes why people are excluded from the financial sector; and the importance, dimensions, and determinants of financial inclusion. After having a clear idea about these main concepts, it will be understood that financial exclusion is a problem that surges from market failure. Therefore, demand and supply forces will help comprehend how the issue is addressed globally.

The following important topic includes a detailed analysis of the Peruvian financial inclusion environment and the selected emerging countries: Brazil, Kenya, the Philippines, and Pakistan. This analysis will address the environment in each country and select demand and supply-side indicators. On the supply side are FinTechs. Therefore, the sub-section "3.2. Remarkable FinTechs in Selected Emerging Markets" will analyze types of FinTechs, paying particular attention to mobile money operators and neo banks. Afterward, the analysis involves the selected companies and their most essential characteristics, value proposition, business model, revenue model, and more.

Over the last 18 years, Financial inclusion is a topic that has become relevant for developing countries because, according to empirical research, it contributes to reducing the poverty gap and reducing inequalities. Therefore, it is expected that resources could be objectively distributed, resulting in the rise of income levels, and as a result, there will be economic growth (CIA.gov 2021b).

This topic has emerged on the global agenda for sustainable long-term economic growth. Central Banks have addressed it; multinational organizations such as the World Bank, the International Finance Corporation, the United Nations, and more have started many initiatives to achieve financial inclusion in emerging and developed countries. However, there is no consensus about its definition and how it should be measured through the different studies (Amidžić et al. 2014).

One of the reasons this topic raised the attention of governments and Central Banks is the well-documented evidence of the strong relationship between financial development and economic growth. Therefore, financial exclusion is a barrier to economic development. Building inclusive financial systems became a need for governments due to the evidence that access to essential financial services such as savings, payments, and credit can substantially improve poor people's lives (Pinar Ardic et al. 2011).

Nevertheless, financial exclusion is not a simple problem because people could voluntarily be self-excluded and decide not to use financial services because of cultural or religious reasons. On the other hand, people are involuntarily excluded because they do not have enough money or access credits. Likewise, people are excluded due to government failures or market imperfections (Amidžić et al. 2014).

Suppose financial inclusion is acknowledged as a behavioral side issue. In that case, it will be understood that people need to decide and choose to participate in the formal financial system, given the right and appropriate information, the right policies, and the supply of services that meet their needs (Cámara and Tuesta 2014).

In 2006, the World Bank identified that the access to formal financial services and the availability of a supply of financial services at reasonable costs and reasonable quality was an objective standard for financial institutions and governments. User refers to the current consumers of financial services. At this time, the World Bank identified the need to intersect demand and supply forces to achieve financial access (Claessens 2006). In 2010, the United Nation-UNSGSA, on its first Annual Report to the Secretary-General, defined financial inclusion as the "universal access, at a reasonable cost, to a wide range of financial services 
provided by a variety of sound and sustainable institutions" (United Nations-UNSGSA 2010). This report addressed the positive impacts of reducing poverty and improving social and economic development.

The Consultative Group to Assist the Poor-CGAP_in 2011 defined financial inclusion as the state where all working-age adults have adequate access to financial services provided by formal institutions, such as credits, savings, payments, and insurance. Consequently, the demand side corresponds to all working-age adults, and the supply side corresponds to "formal institutions." These institutions are financial services providers capable of satisfying customers' needs and offering a better value proposition than informal providers (CGAP 2011a).

OECD and the International Network on Financial Education-INFE in 2013 defined financial inclusion relative to the affordable, timely, and adequate access to a range of regulated financial products and services and broadening their use to all segments of the population through the implementation of tailored existing and innovative perspectives including financial awareness and education to promote financial, economic, and social inclusion (Atkinson and Messy 2013).

Barajas et al. (2020) defined this concept as the population's access to financial services, the extent of the use of these services, and their quality and cost. Additionally, it recognizes no consensus about the definition of financial inclusion due to the multiple factors required to be measured, whether for policymakers or supply-side institutions.

In general terms, these definitions point out the need for all people to access financial services to improve their lives. This statement is not just rhetoric, and evidence supports that financial inclusion can augment economic growth. According to Ghosh (2016), first, consumers that can access the formal financial system are likely to increase savings, which will impact the long-term period of their lives; second, with adequate financial inclusion, firms and people will improve their access to credit, and this situation will improve all economic activity.

Nevertheless, it must be observed that high usage levels of formal financial services or broadly spread access points (ATMs) do not necessarily mean an inclusive system. According to Cámara and Tuesta (2014), financial services can be conditioned by socioeconomic factors such as GDP per capita, human capital, legal framework, cultural habits, or development status that make people use these services in a particular manner. Therefore, the usage and access to financial services are considered an output of financial inclusion and not the inclusiveness of the financial system itself. In other words, both dimensions are necessary but not sufficient to measure financial inclusion.

Regarding dormancy among existing accounts, Findex shows there is still a lot of work on usage: 25 percent of account holders in the developing world have not used their accounts for a single deposit or withdrawal in 2016. However, the challenge in Findex data is that backsliding or slow progress in a few big markets is drowning out progress in the rest of the world. The primary reason is India, which is skewing the account dormancy figures significantly because of its large population and extraordinarily high levels of inactivity-at 48 percent of account holders in 2017. If we take India out of the equation, the percentage of inactive account holders in the developing world comes down from 25 to 16 percent (Bull 2018).

Additionally, it must be pointed out that financial inclusion improves poor people's lives and the entire economy in developing countries. For example, according to the UNSGSA (United Nations-UNSGSA 2017), small and medium-sized enterprises (SMEs) represent half of total employment and a third of the GDP in emerging markets. However, their potential is limited due to inequalities in accessing credits and financing (United Nations-UNSGSA 2017). Consistent evidence found that financial inclusion is beneficial for economic growth and the fight against poverty (Bank for International Settlements 2020).

Many benefits of financial inclusion could be synthesized in two key advantages: enhancing innovation and the better use of existing assets. In other words, entrepreneurs 
have incentives to make innovations and create business opportunities when they can access credit and other financial services, unlocking growth and development opportunities. Furthermore, with proper access to the financial system, people can possess multiple uses to their existing assets, transforming them from "dead assets" to liquid assets (Stein et al. 2011).

Given the benefits and awareness of its importance, financial inclusion has received attention from the public and private sectors in recent years because they recognize the potential of including people in the financial system in emerging countries where income levels are growing and the population is increasing (Moreno et al. 2015). In addition, there is proven evidence suggesting that financial inclusion contributes to a more stable banking system, when deposits mainly fund banks, display low marginal costs, and operate within a robust institutional environment (Barajas et al. 2020).

At this point, it must be observed that recent literature does not connect the importance of financial inclusion to traditional financial institutions because banks did not attend to an unprofitable demand that was expensive to provide. Therefore, economic agents such as government agencies, non-government organizations (NGOs), and the informal sector have attended this underserved market. However, market drivers have developed new opportunities, enabled by digital technologies that create business models that make the costs and profits in serving the unbanked more attractive. Accenture estimated in 2015 that bringing excluded adults and businesses into the formal banking sector could generate about USD 380 billion in new revenue for banks (Amidžić et al. 2014). In other words, the urgent needs of consumers drove technology-related companies to innovate and create products for these people. They disrupted what in former timer was an exclusive bank's territory. These innovations are at some point so successful that even banks are now attracted to reach the unbanked in emerging countries. Therefore, by understanding the importance of the topic, it can be identified that many economic agents are interested in obtaining financial inclusion due to the social benefits and its significant economic opportunities.

According to Atkinson and Messy (2013), financial exclusion signifies market failure that implies demand and supply-side factors. Therefore, to find out the causes of this market failure, common themes on each side must be identified: demand and supply.

From the supply side, the following factors include reducing access to and the use of formal financial products and services (Atkinson and Messy 2013):

- $\quad$ Regulatory constraints: The national regulatory frameworks of states can disincentive the ability of financial providers to attract new clients due to higher costs or extra efforts that are not recuperable in the short term. Moreover, risk-averse regulation and its application can deny financial services to some population segments-for example, people from remote rural areas, migrants, and youth. Based on its work in 10 countries in Africa and Asia, CGAP has identified four building blocks for creating and enabling safe DFS regulatory frameworks (CGAP n.d.). The World Bank explored why account ownership varies widely among economies with similar income levels. The study found that account ownership and use of formal savings are higher in economies with more strict consumer protections. Formal saving is also correlated with policies that limit fees and tax incentives to foster financial inclusion (The World Bank 2021). Another research suggests that account owners' use of savings is significantly related to consumer protection. At the same time, formal saving is also associated with regulations that cap account fees and tax incentives to promote financial inclusion (Klapper et al. 2021). Financial regulators can optimize linkages between four distinct policy objectives: financial inclusion (I), financial stability (S), financial integrity (I), and financial consumer protection (P) (or, collectively, "I-SIP"). The findings demonstrate that tradeoffs among the I-SIP objectives are not inevitable and that synergy is achievable. The study's outcome (GPFI SSBs Conference 2021) suggests the need to consider the four I-SIP objectives collectively rather than independently, as is mostly the case so that linkages among them can be optimized. Based on the findings of 
the study in South Africa, the paper puts forth seven guidance statements to optimize the I-SIP linkage that may be helpful for both national-level policymakers and standard-setting bodies as they implement a financial inclusion plan that increases the chances of maximizing synergies and minimizing trade-offs (GPFI SSBs Conference 2021). Additionally, the question of how to craft a regulatory regime that expands access to financial services to the poor through the development of mobile phone financial services but is compliant with AML/CFT standards remains elusive for most governments. Specific AML/CFT regulations related to mobile money have not been issued in many jurisdictions, mainly due to the lack of awareness of the risks these services can pose if the proper controls are not in place. Due to the international standards for AML/CFT, the Financial Action Task Force's $40+9$ Recommendations were designed and issued well before mobile money technology and business models became prevalent; even developed countries have begun to face challenges with their regulation (Chatain et al. 2013).

- Risks of mobile money: The abuse of mobile money could arise from four primary risk categories-anonymity, elusiveness, rapidity, and poor oversight. Poor oversight is an external risk factor potentially creating conditions that increase the likelihood of abuse stemming from the other three major risk categories. National authorities have prime responsibility for the quality of oversight. Low amounts of money, traceability, and the monitoring features of mobile money programs could make mobile money far less risky than other payment methods, particularly cash. Increasing evidence suggests that certain jurisdictions are implementing overly stringent risk mitigation techniques for money laundering and financing of terrorism, potentially increasing regulatory compliance costs among money providers and constraining financial inclusion objectives (Chatain et al. 2013).

- Inclusion and integrity alignment: There is a noticeable trend of mandatory registration of users of prepaid SIM cards in Sub-Saharan Africa. More than 30 countries have started or are planning to register users of prepaid SIM cards. One immediate effect of registration is that the number of active cellular subscriptions drops due to disconnections. Moreover, penetration growth, measured as year-to-year changes in mobile cellular subscriptions per 100 inhabitants, is depressed due to increased paperwork. Customer identification can become, in particular, a constraint in countries with an insufficient identification infrastructure if no alternative methods for identification are allowed. The share of prepaid subscriptions out of total subscriptions is, on average, around 97 percent for the sampled countries. Therefore, the sheer size of the markets merits a preliminary analysis of the potential effects of mandatory registration (Jentzsch 2012).

- Weak financial consumer protection: Financial services suppliers can attract customers and keep them in a cycle of credit that is too large to manage or too hard to repay.

- Prohibitive market factors: Providers exclude sections of the population with some actions such as denying access to credit to those without credit records, charging high fees for basic transactions, designing terms and conditions to exclude, for example, the informal sector, and promoting marketing in favor to specific groups. These actions tend to exclude unprofitable or high-risk populations.

- Geographical/physical barriers: Normally, people access financial services through physical locations. However, geographical and physical barriers such as remote rural and isolated areas and poor infrastructure make it impractical to provide branch services. This situation is that many potential customers are not served or underserved. Infrastructure and connectivity barriers: The barriers are currently being reduced due to easy access to information technologies such as mobile telephones and computers. However, parts of the population are still excluded where electricity is unavailable and technology requires compatible products.

The demand-side factors are the following (Atkinson and Messy 2013): 
- The financial vulnerability caused by personal circumstances: This includes issues such as lack of money or resources, no credit history, unemployment, lower-income or intermittent income, and others that discourage people from accessing financial products from the formal sector and giving a chance to informal moneylenders to operate, which increases the vulnerability of poor households and reduces the possibility of being involved in the traditional financial system.

- Low levels of financial literacy: Studies show a relationship between financial literacy and financial inclusion. A lack of awareness, low confidence and trust, and insufficient knowledge create barriers and discourage people from accessing financial products.

- $\quad$ Reduced social-technological inclusion: Some sectors of the population in some countries are isolated through different causes such as geographical barriers or inadequate infrastructure. However, despite mobile phones' advantages, such as fast and easy access to a mobile bank account, these people may lack knowledge or familiarity with some technologies, such as the internet and mobile phone features. These issues are perceived as a barrier to financial inclusion.

- Cultural and psychological barriers: Some population sectors can consciously decide to self-isolate from financial services due to personal, cultural, and religious beliefs. Additionally, barriers can be considered a lack of trust in the financial sector and the "outsiders."

- Linguistic or educational barriers: Attached to the lack of financial literacy, there are situations in which people speak a different language than the supplier's language. Therefore, they are not familiar with the vocabulary used by the financial sector. Moreover, these communicational barriers can be exacerbated if these population sectors have lower general education levels, such as limited literacy and numeracy.

After reviewing supply and demand-side causes of financial inclusion, it can be said that from the supply side, both banks and FinTechs are called to adjust their priorities, business models, goals, products, and services to reach population financially excluded due to many benefits that will be explained in the next section. From the demand side, there are countless methods for measuring financial inclusion. Nevertheless, the demandside indicators chosen are used commonly in the literature, such as the ownership of a bank account, mobile money account, credit and debit card, the ability to make savings or borrowings in a financial institution, and making remittances (Sotomayor et al. 2018; United Nations-UNSGSA 2010).

Financial inclusion is a multidimensional topic. However, the terminology varies depending on the purpose of the research project. In addition to this, the studies reviewed have in common that the problem underneath is a market failure. Therefore, supply and demand forces are the basis for every survey, and the dimensions serve to classify and measure specific indicators.

According to Amidžić et al. (2014), there are three main dimensions: outreach, usage, and quality of financial services. The outreach dimension refers to the physical possibility to reach a point of service. The usage dimension refers to the use of financial services, and the quality dimension refers to the extent to which financial services address consumers needs.

Cámara and Tuesta (2014) analyzed the dimensions of usage, barriers, and access to financial services. The first measures the extent of usage of formal financial services; the second refers to the unbanked obstacles that discourage them from using traditional financial services. The third refers to the possibility of using legal financial services when they meet the population's needs.

According to Pearce and Ortega (2012), the dimensions are access, usage, and quality. With the access is measured the extent of costumers who will adopt new financial services and products from formal institutions; the use measures the regularity and frequency of the adoption of financial services and products and the quality, the degree to which consumers are benefitted from financial services. This study includes the consumer protection framework and the promotion of financial literacy. 
Another exciting approach made by Sotomayor et al. (2018) explains that the determinants for financial inclusion are the environment in which the Financial Sector operates: the supply side, which in the literature is referred to the access to financial services and products; and the demand-side, referred to the usage of those products and services and their consumption. The author affirms that supply and demand forces alone will hardly achieve a situation where the population can access financial services and use them. Therefore, it is essential to consider the country's environmental factors.

Financial inclusion is positioned prominently as an enabler of other developmental goals in the 2030 Sustainable Development Goals, where it is featured as a target in eight of the seventeen goals. These include SDG 1, on eradicating poverty; SDG 2 on ending hunger, achieving food security, and promoting sustainable agriculture; SDG 3 on profiting health and wellbeing; SDG 5 on achieving gender equality and economic empowerment of women; SDG 8 on fostering economic growth and jobs; SDG 9 on supporting industry, innovation, and infrastructure; and SDG 10 on reducing inequality. Additionally, in SDG 17, on strengthening the means of implementation, there is an implicit role for greater financial inclusion through more significant savings mobilization for investment and consumption that can spur growth (UNCDF n.d.).

In consequence, according to Sotomayor, there are three main groups of indicators. The first group is related to the financial sector's environment; the second calls the supply forces controlled by the financial service providers; and finally, the third group refers to demand-side characteristics. Similar to any other market, these factors interact and influence financial inclusion in a country (Sotomayor et al. 2018).

This study analyzes carefully each dimension provided by the authors. However, not all of them can be taken or further developed since those classifications are not suitable for this research project. Furthermore, the research project thesis aims to present in this study a simple approach that has into consideration state-side indicators as well. Therefore, the approach considered by Sotomayor et al. (2018) fits perfectly to solve the problem statement and research questions. For this reason, it is essential to explain the understanding of these main dimensions (Sotomayor et al. 2018):

- $\quad$ The environmental side refers to the macroeconomic context, geographical characteristics, vial and telecommunications infrastructure, and public policy.

- The supply side refers to financial institutions' objectives, priorities, characteristics, business models, products, and services offered.

- The demand side refers to the access and use of financial services and macroeconomic indicators such as income level, employment rate, financial education, and similar factors.

The acknowledgment of these three dimensions is relevant because of its clear, direct, and straightforward approach and a practical method for understanding financial inclusion as a market failure problem. In this country's regulation, supply and demand-side forces must be considered.

The recognition of the multidimensional aspects of this topic confirms its complexity; therefore, it is essential to limit the extent of a group of indicators to analyze. By analyzing supply and demand indicators, abundant literature can be found; however, since it is part of this study to analyze FinTechs based in different countries worldwide, the environment indicator has equal importance.

\section{Empirical Research}

This section contains the description of the methodology in Section 3.1, which explains the research design applied, the research questions, and the hypotheses. Moreover, the type of data analyzed and from where it was collected will be presented.

Sections 3.2 and 3.3 conduct a qualitative analysis of the data collected from remarkable Fintechs in the selected emerging countries (supply side) and the relevant information of the respective country (environment and demand-side). After each section, a summarized benchmarking collects data about countries and FinTechs. 
Section 3.4 will conduct a quantitative analysis to understand if the studied companies have a role in the financial inclusion of their respective country. Most of the companies analyzed indicate their essential part in expanding financial services among their targets. However, the results alone require the context of the respective country and a clear explanation of the company's business model to understand why there is a lower or negative correlation in each case.

\subsection{Methodology}

The researchers conducted an exploratory and descriptive research design, following the approach of Malhotra (2010): (1) the information needed for this study, (2) define the research type, (3) specify measurement procedures, (4) the collection of data, (5) specify the process of data collection, and (6 plan of data analysis.

The primary purpose of this research is to search for lessons that could be learned from great FinTech companies in Kenya, Brazil, the Philippines, and Pakistan to help financial inclusion in Peru. These companies were selected after preliminary literature review research in which researchers developed case studies on specific FinTech companies based in those countries (Damodaran 2013; McKay and Pickens 2010; CGAP 2011b; Mauree and Kohli 2013).

The most suitable research design to solve this problem statement and research questions are to conduct a mixed approach combining qualitative and quantitative methods to complement and understand the outcome of this study with insights from both qualitative and quantitative approaches correctly (Malhotra 2010).

The strength of this approach will provide a pragmatic point of view of the problem statement because the data to be analyzed will help answer the research questions and their circumstances (Johnson and Christensen 2004).

The following section will formulate the research questions (RQ) to solve the problem statement by considering a quantitative and qualitative approach:

- $\quad$ RQ1: Does FinTech (a) have a role in financial inclusion in Country (A)?

- RQ2: Which characteristics of the business model of FinTech (a) could be applied to the Peruvian context?

Where:

- $\quad$ FinTech (a) can be either: M-PESA, Nubank, GCASH, or Easypaisa;

- $\quad$ Country (A) can be either: Kenya, Brazil, the Philippines, or Pakistan.

The FinTechs selected for this research project is M-PESA in Kenya, Nubank in Brazil, GCASH in the Philippines, and Easypaisa in Pakistan. Several researchers studied these companies, indicating their participation in financial inclusion in their respective countries. However, there is no clear evidence about the relationship between each FinTech and the financial inclusion indicators in the respective country, except for M-PESA, a company widely known due to its positive impact on financial inclusion in Kenya.

Therefore, the purpose of the RQ1 is to perform a case per case analysis to determine each company's role in financial inclusion in its country. Thus, the researchers conducted a quantitative approach to find a Pearson correlation between the percentage of the population of Country (A) that are users of the FinTech (a) and the six selected demand-side indicators per country retrieved from the Global Findex Database (Jentzsch 2012). This analysis provided insightful data regarding the impact of the selected FinTech on financial inclusion in the respective country.

After solving RQ1, the following hypotheses should be confirmed or rejected.

Hypothesis 1a (H1a $\left.\mathbf{C}_{\text {Country }[\mathrm{A}]}\right)$. FinTech (a) has a role in financial inclusion in Country (A).

Hypothesis $\mathbf{1 b}$ (H1) $\left.\mathbf{b}_{\text {Country [A] }}\right)$. FinTech (a) has had o role in financial inclusion in Country (A). 
If the H1a is confirmed, lessons are learned from its business model and environment. However, if the $\mathrm{H} 1 \mathrm{~b}$ is approved, it is possible to identify specific factors that impede the successful performance of a Fintech in its respective country.

This quantitative approach provides essential information regarding the performance of each company in the financial inclusion in the respective country. However, to understand the results, it is necessary to consider the context of each company and the respective country. Thus, the purpose of the RQ2 is to gather qualitative data by benchmarking the selected FinTechs' business models after understanding each company and country's context. For this reason, first, qualitative information is collected and analyzed to understand which lessons can be learned in each to complement and understand the quantitative analysis results properly.

For the quantitative part of this research, the principal source of information is public data provided by the Global Findex Data, Statista, Annual Reports, and specific information from the World Bank database. For the qualitative part of this research, secondary data were gathered from annual reports, previous research studies, and the respective website of the respective FinTech. Likewise, when the information needed was not available, the information was collected from Central Banks, Statista, or similar types of institutions.

In Figure 1, the research design is presented with problem statements, research questions, and approaches used to solve them.

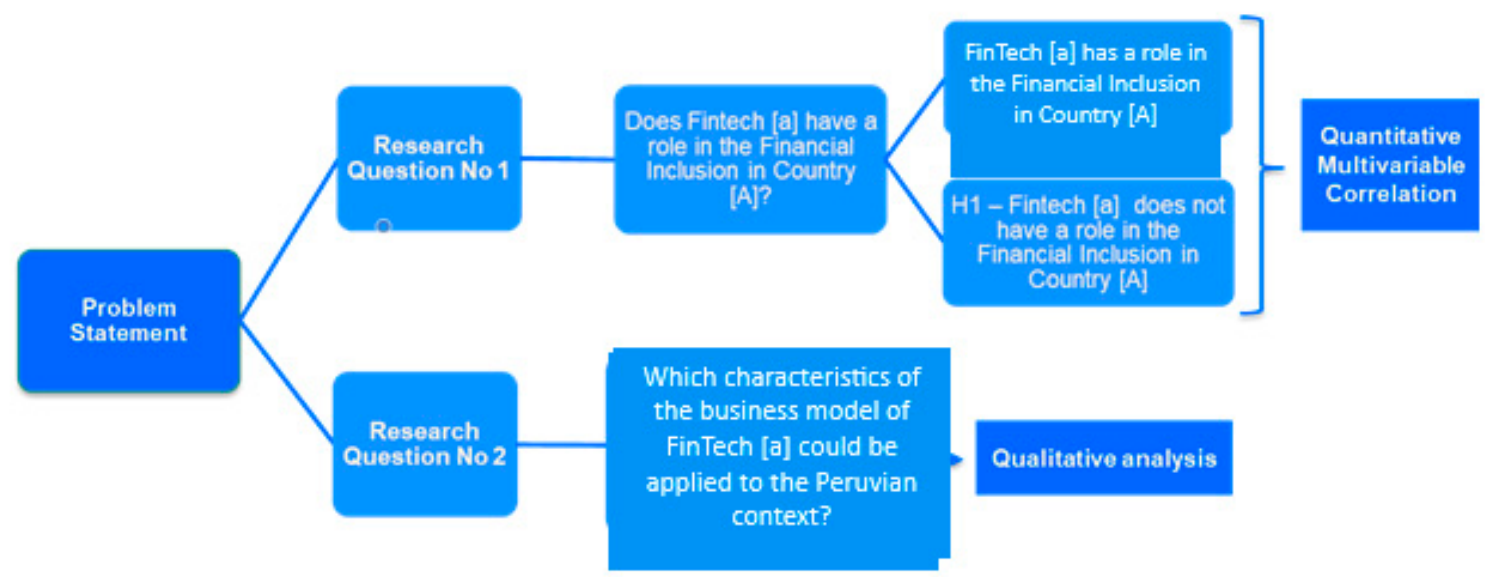

Figure 1. Research design. Source: own construction of the authors.

\subsection{Remarkable FinTechs in Selected Emerging Markets}

This section analyzes the supply side of financial inclusion by researching remarkable examples of FinTechs, studied previously by different researchers and international organizations due to their innovative financial products in emerging markets. Searching for successful or outstanding FinTechs playing a role in the financial inclusion in their respective home countries was very challenging since enthusiastic researchers analyze cases of certain FinTechs. Nevertheless, after some years, the companies' performance information was discontinued; therefore, no updated knowledge can help diagnose these companies through the years. Some examples are Oi Paggo in Brazil and Wizzit in South Africa. Another reason why some companies were excluded from this study is that the environment in which they operate is not comparable to the Peruvian territory. For example, Alipay in China and Eko in India are often studied as successful case studies (McKay and Pickens 2010; Scharwatt et al. 2014). The Indian and Chinese cases were excluded for reasons related to the environment in which they flourished.

The environmental factors are exogenous conditions under which the financial sector operates. Its importance must be taken into consideration because they influence the development and performance of the entire system. These factors are mainly macroeconomic context, geographical characteristics, public policies, infrastructure, and others that impact the supply and demand forces (Sotomayor et al. 2018). According to Rojas-Suarez and 
Gonzales (2010), a precise comparison regarding financial inclusion should be between countries at a similar stage of development. This is due to the specific country characteristics and because companies adapt their services and deliver a value proposition that suits people's needs (Braga et al. 2013). Therefore, the authors excluded highly developed countries and long-term outperforming emerging countries, such as China and India. The latter had a high dynamic economy, a pro-growth agenda, large competitive companies, and deep connections to the global economy, adapting its international macroeconomic practices to their local contexts over the last three decades (McKinsey Global Institute 2018).

Peruvian context is not the same since the economic performance of this country was improving over the last two decades thanks to this country's outstanding financial performance. However, due to the political instability, economic constraints, and the worst recession in the region due to the COVID-19 pandemic, this nation cannot outperform emerging countries for this study.

The chosen companies for this study are M-PESA from Kenya, Nubank from Brazil, G-Cash from the Philippines, and Easypaisa from Pakistan due to their participation in the financial inclusion in their respective countries and because of the existence of previous study cases in which value proposition and business models that could have an impact and contribution to financial inclusion in their respective countries were found (Damodaran 2013; McKay and Pickens 2010; CGAP 2011b).

These companies are remarkable due to their important achievements, value proposition, and problems they solve, and because all of them currently target the unbanked. In the following paragraphs, the business models of each of the previously mentioned companies will be analyzed, considering some elements used by the IFC (International Finance Corporation 2011), which are the business' objective, strategy, target market, marketing strategy, revenue streams, costs, transactions, users, pipeline, and model and partners.

\subsubsection{M-PESA}

In Kenya, the most remarkable example of a FinTech that improved financial inclusion in this country is the case of M-PESA, the first product of its kind introduced in Kenya viewed as a successful implementation of a mobile money service that can serve as a model in developing countries (UNCDF n.d.). In general, it was proven that poor people improved their lifestyles significantly thanks to M-PESA (Barajas et al. 2020). The business model of this company is shown in Table 3.

Table 3. M-PESA's business model.

\begin{tabular}{ll}
\hline Key Characteristics & \multicolumn{1}{c}{ Analysis } \\
\hline Business objective & $\begin{array}{l}\text { According to the IFC, M-PESA delivers a simple, fast, safe, and easy } \\
\text { method to move money across the country. Their main message was the } \\
\text { simple phrase "send money home," which immediately engaged } \\
\text { Kenyans (International Finance Corporation 2009). }\end{array}$ \\
& $\begin{array}{l}\text { M-PESA carefully planned several agents according to customers and } \\
\text { transactions to achieve its value proposition. In the beginning, registered } \\
\text { customers were enabled to send money to non-registered users with an } \\
\text { extra fee paid by the first ones. This entire strategy created viral } \\
\text { registration and active and committed agent networking. } \\
\text { However, M-PESA had to sign up a deal with the Kenyan Commercial } \\
\text { Bank (KCB) to keep money flowing in agent-to-agent transactions. This } \\
\text { improvement improved the availability of M-PESA in the market } \\
\text { (International Finance Corporation 2009). }\end{array}$ \\
& $\begin{array}{l}\text { The early tactic of M-PESA to gain customers was targeting the poor } \\
\text { through a bottom of pyramid approach and taking advantage of } \\
\text { Safaricom's market share and their large customers base for rapid growth } \\
\text { in the country (Ngugi et al. 2010). }\end{array}$ \\
\hline
\end{tabular}


Table 3. Cont.

\begin{tabular}{|c|c|}
\hline Key Characteristics & Analysis \\
\hline Marketing strategy & $\begin{array}{l}\text { The marketing strategy focused on customer education and aggressive } \\
\text { advertisement of their products and services by television, radio, and } \\
\text { social media. } \\
\text { The strategy also engages local culture through a catchy advertising jingle } \\
\text { and nationalistic branding (International Finance Corporation 2009). }\end{array}$ \\
\hline Revenue streams & $\begin{array}{l}\text { According to the Annual Report of Safaricom 2020, the revenue stream of } \\
\text { M-PESA consists basically of mobile money transfers and payment } \\
\text { services. This daughter company contributes } 33.6 \% \text { of Safaricom's } \\
\text { revenue (McKay and Pickens 2010). In the previous years before the } \\
\text { pandemic, M-PESA's revenue is continuously growing despite the } \\
\text { COVID-19 crisis. The revenue in } 2020 \text { was EUR } 655.32 \text { million }(84,438 \\
\text { million Kenyan Shillings) (Safaricom PLC 2020). }\end{array}$ \\
\hline Transactions & $\begin{array}{l}\text { M-PESA has increased its number of transactions in recent years. When } \\
\text { the product was launched, the transactions were deposit cash, withdraw } \\
\text { cash (registered or non-registered users), and commission per M-PESA } \\
\text { customer registration (International Finance Corporation 2009). } \\
\text { Currently, according to Safaricom (Safaricom PLC 2020), the transactions } \\
\text { with a charged fee are withdrawal from M-PESA agent, transfer to } \\
\text { unregistered users, transfer to other M-PESA users, and transfer to other } \\
\text { mobile money users. Other free-of-charge transactions are deposits, } \\
\text { M-PESA registration, buying airtime through M-PESA, M-PESA balance } \\
\text { inquiry, and change of M-PESA PIN (Safaricom 2021). As an example of } \\
\text { one transaction cost of this company, a withdrawal from an M-PESA } \\
\text { agent is free of charge when the amount is between (in Kshs) } 1 \text { and } 49 \\
\text { (0.0078-EUR 0.38). Nonetheless, when the amount is between } 100 \text { to } 500 \\
\text { (0.77-EUR 3.87), the charges to M-PESA are } 27 \text { (EUR 0.21). Then the costs } \\
\text { for this company increase accordingly to the withdrawn amount. The } \\
\text { highest possible withdrawal is between 50,001 and 150,000 (EUR } \\
\text { 388.2-1164.57), and the charge is } 300 \text { (EUR } 2.33 \text { ) (CGAP 2011b). }\end{array}$ \\
\hline & $\begin{array}{l}\text { Safaricom's financial products through M-PESA offers are all based on } \\
\text { mobile money solutions for wealth management, banking, credit, and } \\
\text { insurance products. These products are as follows (Safaricom PLC 2021): }\end{array}$ \\
\hline Main products & $\begin{array}{ll}\text { - } & \text { M-PESA for transfers and payments; } \\
\text { - } & \text { M-Shwari and KCB M-PESA for micro-savings and credits; } \\
\text { - } & \text { Lipa Na-MPesa allows cashless payments for goods and services; } \\
\text { - } & \text { M-PESA Global makes merchant interoperability, e-commerce, and } \\
\text { cross-border payments possible. This product has partnerships } \\
\text { with PayPal, Google Playstore, Western Union, Visa, AliExpress, } \\
\text { and over } 28 \text { other international partners. }\end{array}$ \\
\hline
\end{tabular}

According to the Annual Report of 2021 of Safaricom, M-PESA has 28.21 million customers (Safaricom PLC 2021). In 2011, 2014, and 2017, the registered users of this company were 13.8 million, 19.3 million, and 27 million (Safaricom 2011, 2014, 2017).

Safaricom chose the SIM Toolkit (STK) technology with SMS delivery for delivering mobile money transactions. With STK, the user has an application on the mobile phone's SIM card accessed from the phone's menu. This technology offers high levels of security and usability but does need the SIM card to be changed. Therefore, Safaricom provides help for users in this process International Finance Corporation (2009).

Technology applied

M-PESA was a pioneer mobile money service that began without competitors, and due to its dynamic services and products approach, it is

Competitors the leading mobile money provider. By 2020 the main competitors were Airtel Money and T-Cash.

Source: own illustration based on the guidelines for business model analysis in Mobile Money Study (International Finance Corporation 2011) and specific M-PESA information gathered from different sources. 
The analysis of M-PESA's business model presents a very successful company that began targeting the poorest, enabling them to realize safe and straightforward transactions committed with financial inclusion in Kenya. Furthermore, the company evolved since its beginnings because it provides more services than transfer money solutions, including banking, insurance services, and expansion possibilities through e-commerce and crossborder payments.

Controversially, the regulation in Kenya also allowed a mobile network operator to play a leading role in providing bank services, despite not holding a bank license. Notwithstanding these concerns, the Central Bank of Kenya agreed to issue a letter of no objection to allow mobile money to observe in the marketplace to inform later regulation. M-PESA has proved spectacularly successful, transforming the Kenyan economy and turning Kenya into a global trendsetter in mobile money (de Koker et al. 2020). M-PESA is not regulated under a full banking license; thus, it is essentially operating outside of the traditional banking regulatory environment. Still, it has been audited by the Central Bank and has received its approval for operation. This is by the European Mobile Payment Directive, which establishes the role of payment service providers in the financial system. Banks in Kenya are aggressively lobbying the Central Bank to require M-PESA to adhere to complete banking regulations or halt the service. Safaricom is keen to see the Central Bank implement the official regulatory policy that will open up the market for deposit-taking, clearing systems, and know-your-customer rules to incorporate the activities of mobile operators. Safaricom and Vodafone have maintained a strong relationship with the Central Bank of Kenya. The Kenyan government owns 35\% of Safaricom and may have made it easier to approve the regulation (International Finance Corporation 2009). This approach also resulted in its current market dominance, limiting space for competitors.

Regarding M-PESA's future outlook, this company has a robust and coherent business model targeting the needs of millions of unbanked in Africa. It is probably one of the best companies in this sector. Therefore, their recent partnerships with Western Union, PayPal, Visa, and many others open a broader possibility to attend to other markets adapting their business model to the respective market.

\subsubsection{Nubank}

Nubank is a Brazilian start-up company that provides financial services, acting mainly as a credit card operator in the domestic market. The business model of this company is shown in Table 4.

Table 4. Nubank's business model.

\begin{tabular}{ll}
\hline Key Characteristics & \multicolumn{1}{c}{ Analysis } \\
\hline & $\begin{array}{l}\text { The principal value proposition of Nubank is to provide a credit card } \\
\text { service, } 100 \% \text { digital, without annuities and fees from their clients, totally } \\
\text { manageable by the user on their mobile application, while providing a } \\
\text { personalized, friendly, and agile service. It has to be highlighted that one } \\
\text { of the essential points of this value proposition is the approach of a 100\% } \\
\text { digital bank feature of Nubank because it reduces the physical contact } \\
\text { with the company and also reduces enormous costs for the company } \\
\text { since it does not have personnel handling costumes (Sirota and Fratini } \\
\text { 2018). Nubank's characteristics are their cheap, fast, and convenient } \\
\text { products. }\end{array}$ \\
$\begin{array}{l}\text { Nubank proposes "end any complexity and return the financial control" } \\
\text { to their users. By changing the relationship between people and how } \\
\text { people treat their money, FinTech offers a different approach to banking. }\end{array}$ \\
It aims to solve the most common problems that the Brazilian user has \\
while dealing with banks and their finances, related to the complexity of \\
the Financial Sector and the lack of transparency (Sirota and Fratini 2018).
\end{tabular}


Table 4. Cont.

\begin{tabular}{ll}
\hline Key Characteristics & \multicolumn{1}{c}{ Analysis } \\
\hline & $\begin{array}{l}\text { The original target group that Nubank tried to reach was upper-class } \\
\text { "millennials" and young professionals. People under 36 years old are } \\
\text { born in a digital era and are used to being in contact with technology and }\end{array}$ \\
& sophisticated smartphones (Macedo et al. 2017). However, after the \\
& service became popular, the customer base expanded to different ages \\
Target market & Nubank presented a cheap option to facilitate access to credit cards \\
& (Nubank 2021).
\end{tabular}

Nubank employed considerable efforts in its marketing strategy because the main channel of marketing disclosure was through digital tools. They rapidly took advantage of every chance of spreading their services in a friendly, relaxed, personalized manner, providing quick and effective solutions. Therefore, this approach generated a positive marketing effect, reaching more customers, motivated by the network effect and marketing Marketing strategy promotions to "accelerate their friends" to join Nubank's services. In this manner, it could be said that Nubank's marketing strategy relies on its brand awareness, digital marketing friendly approach, and the network effect of customers. Nubank also used traditional methods on special Brazilian festive days by gifting souvenirs and encouraging them to present them on social networks, spreading the brand using people's networks for that purpose (Nubank 2021).

As previously explained, the main benefit of Nubank is the lack of fees. However, there are two primary revenue streams: the interchange fees on every transaction made with the credit card and taxes over bills and

Revenue streams invoices, which are not pated when due. There are minor sources of income, such as the subscription from "Nubank Rewards." At the beginning of 2021, it is recently known that Nubank reported EUR 1.1 million (6.8 million reals) of revenue for the first time (Banco Central do Brasil 2021).

Nubank is today a digital bank and not only a credit card provider. Therefore, it will not be possible in this section to cover all transactions. However, the transactions that represent an essential revenue stream are the interest on credit card debts that are not paid on time. For example, if the client is a good creditor, the rate could be $4 \%$. If not, it could be up to $13 \%$.

Nevertheless, the average practice by the company is $7.75 \%$. The

Transactions competitors apply an average rate of $8 \%$, which is relatively high compared to other countries (Statista 2021). Furthermore, transactions paid in US dollars will be changed in the domestic currency according to the exchange rate fixed by the Brazilian Central Bank plus four percent of each transaction (Banco Central do Brasil 2021). Consequently, if a purchase of USD 100 is made, Nubank will gain four percent of the conversion rate, which by the 24th of August with an exchange rate of BRL 5.3680 is BRL 21.47 (USD 3.9) (Banco Central do Brasil 2021).

In 2021, this digital bank expanded services for people and businesses, offering a digital bank account, instant payment solutions, remittances

Main products services, credit cards, personal loans, and insurances (Nubank 2021). Furthermore, due to this company's rapid expansion, the partnership with Ripple, a blockchain company, has recently announced the collaboration for their international remittance services.

The growth of Nubank in terms of the customer base is continuously increasing. In June of 2021, Nubank registered 40 million customers. In 2014, the company did not have customers yet, but in 2017, Nubank reported 3 million customers (Statista 2021). 
Table 4. Cont.

\begin{tabular}{ll}
\hline Key Characteristics & \multicolumn{1}{c}{ Analysis } \\
\hline \multirow{3}{*}{ Technology applied } & $\begin{array}{l}\text { Nubank developed a smartphone app that allows customers to apply for } \\
\text { a card, activate it, block and unblock it, manage and pay their bills, } \\
\text { increase and decrease their credit limits, and see their purchase } \\
\text { information in real-time. } \\
\text { Another essential technology developed by Nubank is an advanced data } \\
\text { science infrastructure to process and make decisions about card } \\
\text { applications. }\end{array}$ \\
\hline $\begin{array}{l}\text { Brazil has a highly concentrated traditional banking sector. In 2016, 82\% } \\
\text { of the market was controlled by only five players: Caixa Econômica, Itaú }\end{array}$ \\
Unibanco, Bradesco and Santander. Furthermore, in the last years, other \\
FinTechs such as Digio, Neon, and Intermedium came to the market, \\
offering similar products to Nubank (Nubank 2021).
\end{tabular}

Source: Own illustration based on the guidelines for business model analysis in Mobile Money Study (International Finance Corporation 2011) and specific Nubank's information gathered from different sources.

Regarding all the achievements of Nubank in its relatively short time in the market, it can be said that they are impressive; however, to confirm that this is a successful case could be too early because this company does not yet have a consistent and continuously lucrative performance. According to Banco Data Brazil, this year, Nubank reported revenue of EUR 1.1 million partially, after three consecutive years reporting millions of losses (Safaricom PLC 2020). Therefore, from a conservative point of view, upcoming studies should follow the company's performance in the following years to confirm the success tendency.

\subsubsection{GCASH}

GCASH is a mobile money transfer service that transforms a mobile phone into a virtual wallet for secure, fast, cheap, and easy money transfers. Global Telecom issued an account in this initial phase: the GCASH account. The money is sent by a sender to be withdrawn by the recipient after receiving an SMS alert indicating the amount forwarded to their GCASH account. The task of sending and receiving money was as fast and cheap as a text message (Mauree and Kohli 2013). In the following Table 5, similarly to the analysis of M-PESA and Nubank, the business model of GCASH is presented.

Table 5. G-Cash's business model.

\begin{tabular}{|c|c|}
\hline Key Characteristics & Analysis \\
\hline Business objective & $\begin{array}{l}\text { The value proposition of GCASH is to transform the user's phone to a } \\
\text { mobile account for realizing diverse transactions through prepaid credit, } \\
\text { facilitating the user's self-management to fulfill their needs safely and } \\
\text { affordably. Therefore, the main benefits for customers are safety, } \\
\text { convenience, and low cost (Wishart 2006). }\end{array}$ \\
\hline Strategy & $\begin{array}{l}\text { Globe, in the beginning, did not have partnerships with banks. The } \\
\text { operation and maintenance are performed through a clearinghouse } \\
\text { facility in charge of all transactions and arrangements between retailers } \\
\text { and GCASH customers. Globe's business bank oversaw the money } \\
\text { liquidity management, which did not know about individual users' } \\
\text { activities. Additionally, retailers maintain a balance in the system, used } \\
\text { as the float for transactions with GCASH customers (Wishart 2006). } \\
\text { Therefore, there is a clear strategy of delivering their value proposition } \\
\text { between the system created by the company, involving retailers and } \\
\text { users. Financial institutions provided the logistics to keep money flowing } \\
\text { in their approach. In April of 2021, GCASH partnered with CIMB Bank } \\
\text { to expand digital banking services (S\&P Global Market Intelligence 2020). }\end{array}$ \\
\hline
\end{tabular}


Table 5. Cont.

\begin{tabular}{ll}
\hline Key Characteristics & \multicolumn{1}{c}{ Analysis } \\
\hline Target market & $\begin{array}{l}\text { The target market was to focus at the bottom of the pyramid, especially } \\
\text { young urban consumers familiar with social media (GPFI SSBs } \\
\text { Conference 2021). }\end{array}$ \\
\hline GCASH used different channels such as TV, internet, printed announces, \\
and in-site campaigns to reach more customers. The message mainly \\
focused on cheap, fast, and easy methods to send remittances. \\
Furthermore, the company used humor, celebrities, colorful outfits, and \\
cool ads to make the brand accessible to everyone (CGAP 2011b).
\end{tabular}

The main products are as follows (GLOBE 2021):

- GInvest: allows investing in different investment funds from GCash's reliable partner product providers;

Main products $\quad$ - GCash wallet: allows realizing all types of electronic transactions from the smartphone conveniently;

- $\quad$ GInsure: offers users access to various insurance products;

- $\quad$ GCash app on the smartphone is the platform that supports all GCASH products and transactions.

In June of 2021, Globe reported that GCASH has 33 million users and Users. over 73,000 partner merchants in the Philippines (Safaricom 2017). In 2012, 2014, and 2017, GCASH registered 1.3 million, 3 million, and 5.1 million users (Dalberg 2012; GLOBE 2014; GLOBE 2017).

In the beginning, Globe launched GCASH with the technology known as SMS SKT (SIM Toolkit technology) because in the Philippines was recognized the high levels of SMS usage. Therefore, users could realize

Technology applied transactions through SMS or SIM-based menus and encryption. With this approach, Globe emulated a banking network without having a banking partner (Wishart 2006). However, now GCASH conducts its other products through a mobile app (Mauree and Kohli 2013).

In the Philippines, there exist two leading mobile money providers: Competitors Smart Money, the very first company that launched mobile money solutions in 2001, and GCASH, which expanded better than the competition (Hasnain et al. 2016).

Source: own illustration based on the guidelines for business model analysis in Mobile Money Study (International Finance Corporation 2011) and specific G-Cash information gathered from different sources.

After analyzing this company's business model, similarities with M-PESA can be identified, especially when both parent companies, Safaricom and Globe, launched each product. The technology available was a SIM Toolkit, and people actively used SMS for communication purposes. Therefore, it is an intelligent approach to use a communication 
means for making financial transactions. Another remarkable fact of this company is its rapid expansion and continuous improvement. This company's evolution has not been the same since its beginnings. GCASH today's approach proves this company is adapting to the new times and technologies because it now offers more financial services enabled by the latest technologies, such as the mobile app that supports all GCASH transactions.

\subsubsection{Easypaisa}

Tameer Microfinance Bank, the largest microfinance bank in Pakistan, and Telenor realized a joint venture in 2008 to provide a branchless banking channel to serve existing unserved demand of financial services in Pakistan and generate a new income stream for both companies since each company alone did not have the capabilities to fill the market on their own. The product created by these companies was called Easypaisa, an agent and mobile-assisted payment service, and as a result, Telenor owned 51\% of Tameer's equity structure (Mithe 2015). In Table 6, the business model of Easypaisa is presented.

Table 6. Easypaisa's business model.

\begin{tabular}{|c|c|}
\hline Key Characteristics & Analysis \\
\hline Business objective & $\begin{array}{l}\text { This company was initially launched as a money transfer service, which } \\
\text { empowers underserved masses by providing convenience, trust, and } \\
\text { freedom to their lives by facilitating various mobile money services. } \\
\text { Easypaisa operates as a branchless banking service facilitating their } \\
\text { customers' financial transactions through convenient and fast digitalized } \\
\text { financial services (Easypaisa 2021a). }\end{array}$ \\
\hline Strategy & $\begin{array}{l}\text { Easypaisa is a product created by the partnership of Telenor and Tameer } \\
\text { Microfinance Bank. Each company oversaw the different tasks in the } \\
\text { value chain of this product. Telenor operated the system in the agents' } \\
\text { network, and Tameer was the core of the banking system, which was } \\
\text { highly regulated. Easypaisa focuses on reaching low-cost deposits from } \\
\text { the mass market to lower costs and increase profitability. Another } \\
\text { strategy is to expand their product portfolio by introducing more } \\
\text { innovative and suitable savings products to address customer needs } \\
\text { while reducing capital costs-for example, insurances, credits, and } \\
\text { enabling savings in gold (Mithe 2015). }\end{array}$ \\
\hline Target market & $\begin{array}{l}\text { The target market for the mobile wallet was urban users and people who } \\
\text { already had bank accounts. However, the ads and promotions } \\
\text { considered a more comprehensive range of users in the initial OTC } \\
\text { (over-the-counter) transactions (Easypaisa 2021b). }\end{array}$ \\
\hline Marketing strategy & $\begin{array}{l}\text { The company invested millions of dollars in marketing and produced } \\
\text { high-quality advertisements. For the launch of Easypaisa, Telenor } \\
\text { focused on promoting and establishing the brand as a company that } \\
\text { wants to make people's life easier. In the campaigns, they invested in } \\
\text { education by explaining the functionality of the OTC products and then } \\
\text { mobile wallets. Easypaisa established awareness and trust in the new } \\
\text { brand through video and print ads with educative messages, explaining } \\
\text { that their services provide solutions to payments efficiently and } \\
\text { conveniently (CGAP 2011a). }\end{array}$ \\
\hline Revenue streams & $\begin{array}{l}\text { Revenue is generated from different sources: customers (for transfer } \\
\text { transactions), utility companies (bill payments), and corporate clients } \\
\text { (mass disbursements) (Mithe 2015). }\end{array}$ \\
\hline
\end{tabular}


Table 6. Cont.

\begin{tabular}{|c|c|}
\hline Key Characteristics & Analysis \\
\hline Transactions & $\begin{array}{l}\text { In 2013, the principal transactions enabled by Easypaisa were as follows: } \\
\text { diverse types of payments, P2P transfers, increased air time credits, and } \\
\text { saving money (Mauree and Kohli 2013). Nonetheless, by 2015, more } \\
\text { transactions were enabled, such as domestic and international } \\
\text { remittances, salary disbursements, and savings products combined with } \\
\text { insurances (Mithe 2015). As an example of the costs of one type of } \\
\text { transaction, with withdrawal from an Easypaisa agent (in PKR) is } \\
\text { between } 1 \text { and } 200 \text { (EUR 0.0052-1.04), the charge for the company will be } \\
7 \text { (EUR 0.36). Nonetheless, when the amount is between } 500 \text { to } 1000 \text { (EUR } \\
\text { 2.56-5.12), the charges for Easypaisa are } 20 \text { (EUR 0.1). Then the charges } \\
\text { for this company increase accordingly to the withdrawn amount. The } \\
\text { highest possible withdrawal is between } 40,001 \text { and 50,000 (EUR } \\
207.32-259.15 \text { ), and the charge is } 690 \text { (EUR 3.58) (Easypaisa 2021b). }\end{array}$ \\
\hline Main products & $\begin{array}{l}\text { According to Easypaisa, the current products are mobile banking, } \\
\text { various products, and insurances (Easypaisa 2021b). }\end{array}$ \\
\hline Users & $\begin{array}{l}\text { According to Easypaisa's Annual Report, in 2019, the company registered } \\
30 \text { million customers with a country-wide branch network and over } 150 \\
\text { thousand agents. Telenor continues to be a leader in FinTech in Pakistan } \\
\text { (S\&P Global Market Intelligence 2020). In 2012, 2014, and 2017, Easypaisa } \\
\text { registered } 2 \text { million, } 6 \text { million, and } 19.9 \text { million users (Dalberg 2012; } \\
\text { GLOBE 2014; GLOBE 2017). }\end{array}$ \\
\hline Technology applied & $\begin{array}{l}\text { The technology used by Easypaisa at the beginning was the USSD mobile } \\
\text { money option and at the agent transactions. Later, internet and } \\
\text { smartphone applications were enabled (Mithe 2015; Mauree and Kohli } \\
\text { 2013). For the smartphone applications, the leading technologies used } \\
\text { were a private cloud, real-time screening for customers onboarding on } \\
\text { Easypaisa mobile account, business intelligence analysis, cashless service, } \\
\text { a DDoS functionality for protection against cyber-attacks, and others } \\
\text { (Telenor Microfinance Bank 2017). }\end{array}$ \\
\hline Competitors & $\begin{array}{l}\text { The years after the launch of Easypaisa, other mobile money operators } \\
\text { entered the market. These companies joined in alliance with different } \\
\text { banks and provided various banking services. The principal competitors } \\
\text { are Omni and Mobicash Timepey (Mithe 2015). }\end{array}$ \\
\hline
\end{tabular}

Source: own illustration based on the guidelines for business model analysis in Mobile Money Study (International Finance Corporation 2011) and specific Easypaisa's information gathered from different sources.

The most noticeable fact of this company is its beginnings because it was created with a telecommunications company and a microfinance bank. This situation is different from M-PESA and GCASH because a single company developed these examples from the beginning. Easypaisa evolved rapidly despite the organizational and managerial issues between Telenor and Tameer. According to the literature reviewed, this company continues to lead the mobile money sector and has performed well during the COVID-19 crisis. The company recorded a 35\% increase in new activations, the daily transactions went up by $17 \%$, and the bank transfer via Easypaisa grew by $184 \%$. Furthermore, the company implemented economic relief efforts for customers, free-of-cost disbursements of various government departments and private charities, facilitated donations, helped SMEs embrace digital payments, and many more (Telenor Microfinance Bank 2017).

The literature reviewed found that each company rapidly gained users improving access to financial services in the respective country. In the case of Nubank, it could be said that it is too early to conclude that it is a successful case, but the company improved access to credit cards in a country where the interest rates discouraged many people from access to one.

It was analyzed and verified that each company strived to innovate and develop new, accessible, simple, cheap, and convenient new products in every case. Therefore, all 
selected companies evolved since their initial development and transactions. They started providing specific mobile money services, and after some years, they are now providing mobile banking services without being each of their banks. In Nubank's founder's words, "this company is not a bank but a technology company that offers financial products that meet demand needs (Sirota and Fratini 2018)."

In this research, by comparing each company's progressive growth, it can be confirmed that mobile banking companies have enough incentives to attend to the unbanked financial needs because all of the selected companies are profiting well enough from millions of transactions realized by the adult population, which is continuously increasing in developing economies. Furthermore, the competitiveness in this sector will foster innovation in offering other types of products for farming activities and education. All these positive effects of financial inclusion, according to Bill Gates, will help people to transform their lives in emerging countries radically (Gates 2015).

The information gathered in this subsection will be analyzed after obtaining the Pearson multivariable correlation analysis results in Section 3.4 to solve the second research question through benchmarking, providing lessons for the Peruvian context.

\subsection{The Situation of Financial Inclusion in Selected Emerging Markets}

This section presents the environment-side factors in Kenya, Brazil, the Philippines, and the demand-side indicators, which will help analyze and understand the impact of the selected FinTechs on financial inclusion in each country. After realizing this holistic analysis, it will be possible to find lessons for the Peruvian case.

This paper analyzes the impact of selected FinTech companies in financial inclusion in their respective countries to gain lessons of their business models and country environments that can help Peruvian financial inclusion. The selected FinTechs are M-PESA in Kenya, Nubank in Brazil, GCASH in the Philippines, and Easypaisa in Pakistan, which revolutionized the financial sector in their respective countries. However, a comparative study of their impact on financial inclusion in their respective country has not been performed yet; therefore, the lessons obtained are helpful for the Peruvian situation due to their practical implications and because they raise possible areas for further and deeper research. Even though the financial markets of Kenya, Brazil, the Philippines, and Pakistan analyzed in the study show a great degree of diversity, these countries have been selected primarily because of successful FinTech companies operating there.

The environmental factors are exogenous conditions under which the financial sector operates. Its importance must be taken into consideration because they influence the development and performance of the entire system. These factors are mainly macroeconomic context, geographical characteristics, public policies, infrastructure, and others that impact the supply and demand forces (Sotomayor et al. 2018). According to Rojas-Suarez and Gonzales (2010), a precise comparison regarding financial inclusion should be between countries at a similar stage of development. This is due to the specific country characteristics and because companies adapt their services and deliver a value proposition that suits people's needs (GLOBE 2021). Other topics considered when selecting these countries were similar barriers to financial inclusion, such as the geographical conditions, infrastructure available, and regulatory factors (Barajas et al. 2020; Braga et al. 2013).

In association with the environmental factors, demand-side elements will be presented that provide information regarding access and usage of financial products per country. These factors include socio-economic and demographic characteristics such as financial literacy, multiculturality, employment status, and income levels (Sotomayor et al. 2018).

From the demand side in the selected countries, six out of more than two hundred indicators provided by the World Bank were chosen in a comprehensive dataset called "the Global Findex Database 2017," which covers how adults save, borrow, make payments and manage risk. The last survey round was delivered in 2017, and it includes more than 140 countries in the world (Demirgüç-Kunt et al. 2018). 
The selected indicators for this research project were chosen considering the most preferred financial services in the literature review. These are accounts, mobile money accounts, remittances, credit cards, debit cards, and savings (Stein et al. 2011; Barajas et al. 2020). The Global Findex Database does not include insurance indicators in the dataset for the selected countries. Therefore, the chosen indicators regarding payments, savings, and credits are shown in Table 7.

Table 7. Selected indicators from Findex Dataset (Jentzsch 2012).

\begin{tabular}{|c|c|}
\hline Indicator & Definition \\
\hline $\begin{array}{l}\text { Account ownership (\% } \\
\text { age } 15+\text { ): }\end{array}$ & $\begin{array}{l}\text { It is defined as owning an account either at a formal financial } \\
\text { institution or through a mobile money provider not linked to a } \\
\text { financial institution (Demirgüç-Kunt et al. 2018). }\end{array}$ \\
\hline $\begin{array}{l}\text { Mobile money account } \\
(\% \text { age } 15+)\end{array}$ & $\begin{array}{l}\text { It is limited to services that can be used without an account at a } \\
\text { financial institution. This indicator measures the percentage of people } \\
\text { who used a mobile money service in the past } 12 \text { months } \\
\text { (Demirgüç-Kunt et al. 2018). }\end{array}$ \\
\hline $\begin{array}{l}\text { Sent or received } \\
\text { domestic remittances } \\
\text { through a mobile } \\
\text { phone }(\% \text { age } 15+)\end{array}$ & $\begin{array}{l}\text { Refers to the percentage of people who reported sending to or receiving } \\
\text { money from a relative friend in the same country through a mobile } \\
\text { phone in the past } 12 \text { months (Demirgüç-Kunt et al. 2018). }\end{array}$ \\
\hline $\begin{array}{l}\text { Credit card ownership } \\
(\% \text { age } 15+)\end{array}$ & $\begin{array}{l}\text { Refers to the percentage of people who reported having a credit card. } \\
\text { This is an important indicator because a credit card is a payment } \\
\text { instrument and a source of credit. It is believed that the introduction of } \\
\text { credit cards might have affected the demand for and use of short-term } \\
\text { credit (Demirgüç-Kunt et al. 2018). }\end{array}$ \\
\hline $\begin{array}{l}\text { Debit card ownership } \\
(\% \text { age } 15+)\end{array}$ & $\begin{array}{l}\text { Debit cards are used to make direct payments and withdraw money. } \\
\text { This definition refers to the percentage of people who reported having } \\
\text { a debit card (Demirgüç-Kunt et al. 2018). }\end{array}$ \\
\hline $\begin{array}{l}\text { Saved at a Financial } \\
\text { Institution ( } \% \text { age } 15+)\end{array}$ & $\begin{array}{l}\text { This concept refers to the percentage of people who reported saving or } \\
\text { setting aside money at a bank or another financial institution in the past } \\
12 \text { months. This indicator is important to measure the savings because } \\
\text { having an account does not imply formal savings (Demirgüç-Kunt et al. } \\
\text { 2018). }\end{array}$ \\
\hline
\end{tabular}

\subsubsection{Kenya}

A summarized overview of Kenya is presented in Table 8.

Table 8. Country overview-Kenya.

\begin{tabular}{|c|c|}
\hline Characteristic & Situation \\
\hline $\begin{array}{l}\text { Geographical conditions and } \\
\text { population distribution }\end{array}$ & $\begin{array}{l}\text { Kenya has low plains rising to central highlands bisected by the } \\
\text { Great Rift Valley and a fertile plateau in the west. Area: } \\
224,961 \text { sq. miles. The population in Kenya is very concentrated } \\
\text { in the west along the shore of Lake Victoria, the capital of Nairobi, } \\
\text { and along the Indian Ocean coast (CIA.gov 2021b). }\end{array}$ \\
\hline Population & $\begin{array}{l}\text { The population of Kenya between } 15 \text { and } 64 \text { years was, in the } \\
\text { years 2011, 2014, and 2017, 23.7, 26.1, and } 28.8 \text { million inhabitants, } \\
\text { respectively. In 2020, the population was } 31.7 \text { million (World Bank } \\
\text { 2020c). }\end{array}$ \\
\hline $\begin{array}{l}\text { Infrastructure available } \\
\text { (mobile phone penetration) }\end{array}$ & $\begin{array}{l}\text { By } 2019 \text {, the mobile phone subscriptions per } 100 \text { inhabitants were } \\
104.22 \text { (CIA.gov 2021b). }\end{array}$ \\
\hline
\end{tabular}


Table 8. Cont.

\begin{tabular}{ll}
\hline \multicolumn{1}{c}{ Characteristic } & \multicolumn{1}{c}{ Situation } \\
\hline The rule of law & $\begin{array}{l}\text { According to the Rule of Law index, Kenya is ranked in the 102nd } \\
\text { position out of } 128 \text { countries, and its score is 0.45, which means } \\
\text { law enforcement and the institutions are weak and that there are } \\
\text { corruption problems in this country (The World Justice Project } \\
\text { 2020). }\end{array}$ \\
\hline Financial literacy & $\begin{array}{l}\text { In 2015, a survey found that 38\% of the Kenyan population was } \\
\text { financially literate Klapper et al. 2015). }\end{array}$ \\
\hline Banking concentration & $\begin{array}{l}\text { In 2017,36.6\% of the market was concentrated in a few banks } \\
\text { (World Bank 2020c). }\end{array}$ \\
\hline Multiculturality & $\begin{array}{l}\text { The principal ethnic groups are Bantu, Nilo-Saharan, Afro-Asiatic, } \\
\text { and others. The main languages spoken in this country are } \\
\text { English, Kiswahili, and numerous indigenous languages. In } \\
\text { Kenya, there is religious diversity (CIA.gov 2021b). }\end{array}$ \\
\hline $\begin{array}{l}\text { Employment to population } \\
\text { ratio }\end{array}$ & $\begin{array}{l}\text { In 2019, the pre-pandemic year, the employment rate in Kenya } \\
\text { was 72.31\% (World Bank 2020c). }\end{array}$ \\
\hline $\begin{array}{l}\text { Gross National Income per } \\
\text { capita }\end{array}$ & $\begin{array}{l}\text { In 2020 the GNI per capita was USD 1760 (World Bank 2020c). } \\
\text { Source: own illustration based on specific information about Kenya. }\end{array}$
\end{tabular}

A synthesized diagnosis of the Kenyan context of financial inclusion is shown in Table 9.

Table 9. Selected indicators regarding financial inclusion in Kenya.

\begin{tabular}{cccc}
\hline Indicator & $\mathbf{2 0 1 1}$ & $\mathbf{2 0 1 4}$ & $\mathbf{2 0 1 7}$ \\
\hline Account ownership (\% age 15+): & $42 \%$ & $75 \%$ & $82 \%$ \\
Mobile money account (\% age 15+) & - & $58 \%$ & $73 \%$ \\
Sent or received domestic remittances through a & - & $64 \%$ & $63 \%$ \\
mobile phone (\% age 15+) & $6 \%$ & $5 \%$ & $6 \%$ \\
Credit card ownership (\% age 15+) & $30 \%$ & $35 \%$ & $38 \%$ \\
Debit card ownership (\% age 15+) & $23 \%$ & $30 \%$ & $27 \%$ \\
Saved at a Financial Institution (\% age 15+) & \multicolumn{2}{c}{}
\end{tabular}

For Kenyan's case, it can be said that mobile money accounts, bank accounts, and remittances are more accessible and reliable products than debit or credit cards from this initial data. The low saving culture can be related to a lack of trust in financial institutions, poor financial literacy rates, and the economic constraints of households, considering that Kenya is a lower-middle-income country in Africa. One of the reasons why credit card ownership remains very low in this country can be related to the concurrence of predatory lending by FinTech companies. Due to this reason, the parliament of Kenya considered regulating non-cash payments and establishing an authority called the Financial Market Conduct Authority to oversee FinTech companies. Moreover, a data protection law was implemented to protect personal financial information (Economist Intelligence Unit 2019).

The overall financial inclusion score is above the average $(55 / 100)$ in the region and the group of lower-middle-income peers. The government and policy support, market stability and integrity, and consumer protection rules and infrastructure have an aboveaverage score, indicating that this country's financial inclusion environment is favorable. However, the dimension of products and outlets means challenges because the score obtained (33/100) locates Kenya far under average peer countries in Sub-Saharan Africa and lower-middle-income countries (Economist Intelligence Unit 2019). 
3.3.2. Brazil

Table 10 presents a brief general overview of this country.

Table 10. Country overview-Brazil.

\begin{tabular}{|c|c|}
\hline Characteristic & Situation \\
\hline $\begin{array}{l}\text { Geographical conditions } \\
\text { and population } \\
\text { distribution }\end{array}$ & $\begin{array}{l}\text { The territory of Brazil is primarily flat, but there are some rolling } \\
\text { lowlands in the north, some plains, hills, mountains, and a narrow } \\
\text { coastal belt. Area: } 3 \text { million sq. miles. Most of the population lives } \\
\text { along the Atlantic coast in the east, mainly in Sao Paolo, Brasilia, and } \\
\text { Rio de Janeiro (CIA.gov 2021a). }\end{array}$ \\
\hline Population & $\begin{array}{l}\text { The adult population in Brazil (ages } 15 \text { to } 64 \text { ) in } 2020 \text { was roughly } \\
148.1 \text { million. In 2011, 2014, and 2017, the population was 135.6, 140.7, } \\
\text { and } 144.8 \text { million inhabitants, respectively (World Bank 2016). }\end{array}$ \\
\hline $\begin{array}{l}\text { Infrastructure available } \\
\text { (mobile phone } \\
\text { penetration) }\end{array}$ & $\begin{array}{l}\text { By 2019, the subscriptions per } 100 \text { inhabitants were } 123.76 \text { (CIA.gov } \\
\text { 2021a). }\end{array}$ \\
\hline The rule of law & $\begin{array}{l}\text { According to the Rule of Law index, Brazil is ranked in the } 67 \text { th } \\
\text { position out of } 128 \text { countries, and its score is } 0.52 \text {, which means the } \\
\text { law enforcement and the institutions are weak and that there are } \\
\text { corruption problems in the government (The World Justice Project } \\
\text { 2020). }\end{array}$ \\
\hline Financial literacy & $\begin{array}{l}\text { In 2015, a survey found that } 35 \% \text { of the Brazilian population was } \\
\text { financially literate (World Bank 2016). }\end{array}$ \\
\hline Banking concentration & $\begin{array}{l}\text { In 2017, 56.6\% of the market was concentrated in a few banks (World } \\
\text { Bank 2020a). }\end{array}$ \\
\hline Multiculturality & $\begin{array}{l}\text { The ethnic groups living in Brazil are white } 47.7 \% \text {, mulatto } 43.1 \% \\
\text { (mixed white and black), black } 7.6 \% \text {, Asian } 1.1 \% \text {, and indigenous } \\
0.4 \% \text {. } \\
\text { The most widely spoken language is Portuguese. However, there are } \\
\text { many minor Amerindian languages (CIA.gov } 2021 \text { ). }\end{array}$ \\
\hline $\begin{array}{l}\text { Employment to } \\
\text { population ratio }\end{array}$ & $\begin{array}{l}\text { In 2019, the pre-pandemic year, the employment rate in Brazil was } \\
56.7 \% \text { (World Bank 2020a). }\end{array}$ \\
\hline $\begin{array}{l}\text { Gross National Income } \\
\text { per capita }\end{array}$ & In 2020 the GNI per capita was USD 7850 (World Bank 2021a). \\
\hline
\end{tabular}

A synthesized diagnosis of the Brazilian context of financial inclusion is shown in Table 11.

Table 11. Selected indicators regarding financial inclusion in Brazil.

\begin{tabular}{cccc}
\hline Indicator & $\mathbf{2 0 1 1}$ & $\mathbf{2 0 1 4}$ & $\mathbf{2 0 1 7}$ \\
\hline Account ownership (\% age 15+): & $56 \%$ & $68 \%$ & $70 \%$ \\
Mobile money account (\% age 15+) & - & $1 \%$ & $5 \%$ \\
Sent or received domestic remittances through a & - & $0 \%$ & $1 \%$ \\
mobile phone (\% age 15+) & $29 \%$ & $32 \%$ & $27 \%$ \\
Credit card ownership (\% age 15+) & $41 \%$ & $59 \%$ & $59 \%$ \\
Debit card ownership (\% age 15+) & $10 \%$ & $12 \%$ & $14 \%$ \\
Saved at a Financial Institution (\% age 15+) & &
\end{tabular}

Source: Own illustration based on the Global Findex Database (Jentzsch 2012).

Brazil's overall financial inclusion score is superior to the average in Latin American and Caribbean countries and the group of upper-middle-income countries. The supply side of products and outlets has improved in presence and quality. It could be said that this positive outcome in 2020 was due to the efforts of the government, the Central Bank, and the financial sector of Brazil. 


\subsubsection{The Philippines}

In Table 12, a brief general overview of this country is presented.

Table 12. Country Overview-The Philippines.

\begin{tabular}{|c|c|}
\hline Characteristic & Situation \\
\hline $\begin{array}{l}\text { Geographical conditions and } \\
\text { population distribution }\end{array}$ & $\begin{array}{l}\text { The Philippines is an archipelagic country composed of islands, } \\
\text { mountains, and extensive coastal lowlands. Area: } 115,831 \text { sq. } \\
\text { miles. The population in this country is concentrated where good } \\
\text { farmlands lie, principally in the north of the country (Luzon), } \\
\text { some islands, and in the capital city, Manila, where one-eighth of } \\
\text { the entire national population resides (CIA.gov 2021e). }\end{array}$ \\
\hline Population & $\begin{array}{l}\text { The adult population in the Philippines (ages } 15 \text { to } 64 \text { ) in } 2020 \\
\text { was roughly } 70.6 \text { million. In 2011, 2014, and 2017, the population } \\
\text { was 59.3, 63.1, and } 66.8 \text { million inhabitants, respectively (World } \\
\text { Bank 2021a). }\end{array}$ \\
\hline $\begin{array}{l}\text { Infrastructure available } \\
\text { (mobile phone penetration) }\end{array}$ & $\begin{array}{l}\text { By 2019, the subscriptions per } 100 \text { inhabitants were } 155.61 \\
\text { (CIA.gov 2021e). }\end{array}$ \\
\hline The rule of law & $\begin{array}{l}\text { According to the Rule of Law index, the Philippines is ranked in } \\
\text { the 91st position out of } 128 \text { countries, and its score is } 0.47 \text {, which } \\
\text { means that law enforcement and the institutions are weak and } \\
\text { that there are corruption problems in the government (The World } \\
\text { Justice Project 2020). }\end{array}$ \\
\hline Financial literacy & $\begin{array}{l}\text { In } 2015 \text {, a survey found that } 25 \% \text { of the population was financially } \\
\text { literate (Klapper et al. 2015). }\end{array}$ \\
\hline Banking concentration & $\begin{array}{l}\text { In } 2017,47.4 \% \text { of the market was concentrated in a few banks } \\
\text { (World Bank 2021a). }\end{array}$ \\
\hline Multiculturality & $\begin{array}{l}\text { This country is culturally very diverse. There are more than seven } \\
\text { ethnic groups dispersed in its territories. Therefore, there are } \\
\text { many languages and dialects as well. Nevertheless, the official } \\
\text { language is Filipino and English (CIA.gov 2021e). }\end{array}$ \\
\hline $\begin{array}{l}\text { Employment to population } \\
\text { ratio }\end{array}$ & $\begin{array}{l}\text { In 2019, the pre-pandemic year, the employment rate in the } \\
\text { Philippines was } 58.79 \% \text { (World Bank 2021a). }\end{array}$ \\
\hline $\begin{array}{l}\text { Gross National Income per } \\
\text { capita }\end{array}$ & In 2020, the GNI per capita was USD 3430 (World Bank 2021a). \\
\hline
\end{tabular}

Before the COVID-19 crisis, the country had made progress in inclusive growth, declining poverty rates, and increasing real wages, which generated dynamic consumption behaviors. Table 13 presents a synthesized diagnosis of the Philippines' context of financial inclusion.

Table 13. Selected indicators regarding financial inclusion in the Philippines.

\begin{tabular}{cccc}
\hline Indicator & $\mathbf{2 0 1 1}$ & $\mathbf{2 0 1 4}$ & $\mathbf{2 0 1 7}$ \\
\hline Account ownership (\% age 15+): & $27 \%$ & $31 \%$ & $34 \%$ \\
Mobile money account (\% age 15+) & - & $4 \%$ & $5 \%$ \\
Sent or received domestic remittances through a & - & $6 \%$ & $5 \%$ \\
mobile phone (\% age 15+) & $3 \%$ & $3 \%$ & $2 \%$ \\
Credit card ownership (\% age 15+) & $13 \%$ & $20 \%$ & $21 \%$ \\
Debit card ownership (\% age 15+) & $15 \%$ & $15 \%$ & $12 \%$ \\
Saved at a Financial Institution (\% age 15+) & & & \\
\hline
\end{tabular}

Source: own illustration based on the Global Findex Database (Demirgüç-Kunt et al. 2018).

The indicators of financial inclusion in the Philippines are low. Account and debit card ownership represents the higher percentage, showing progress through the years. 
However, the other indicators remain low. These results indicate an essential gap to provide suitable financial products and services to the population's needs.

This country, since 2016, has created a governmental institution that guides and oversees the implementation of the National Strategy for Financial Inclusion, which places a particular focus on digital financial inclusion and financial and digital literacy. However, an important issue was ensuring interoperability in retail payments because of the limited number of operators and the high transaction costs (Economist Intelligence Unit 2019).

The present outlook of financial inclusion in the Philippines is promising. This country was recognized in 2016 as an ideal place for developing digital and financial products and services due to its large young population, positive annual GDP growth, fast-growing internet penetration, and mobile phones engagement. Therefore, Smart Money and GCASH approached this market in new ways (Hasnain et al. 2016).

The overall financial inclusion score is higher than peers in East and South Asia and higher than in lower-middle-income countries. This outcome is a positive sign that the measures introduced by authorities since 2016 may have provided better governmental and policy support, stability to the financial system, and consumer protection rules. Therefore, the supply of products and services has increased, and this country's overall financial inclusion situation has improved. However, there are still gaps to improve, especially regarding implementing adequate infrastructure to connect this country's remote rural and low populated areas.

\subsubsection{Pakistan}

In Table 14, a brief general overview of this country is presented.

Table 14. Country overview-Pakistan.

\begin{tabular}{|c|c|}
\hline Characteristic & Situation \\
\hline $\begin{array}{l}\text { Geographical conditions and } \\
\text { population distribution }\end{array}$ & $\begin{array}{l}\text { The territory of this country is divided into three major } \\
\text { geographic areas, the northern highlands, the Indus River plain in } \\
\text { the center and east, and the Balochistan Plateau in the south and } \\
\text { west. Area: } 339,697 \text { sq. miles. The population in this country is } \\
\text { concentrated in the largest cities, such as Karachi and Lahore } \\
\text { (CIA.gov 2021c). }\end{array}$ \\
\hline Population & $\begin{array}{l}\text { The adult population in Pakistan (ages } 15 \text { to } 64 \text { ) in } 2020 \text { was } \\
\text { roughly } 134.3 \text { million. } \\
\text { In } 2011,2014 \text {, and 2017, the population was } 107.1,116 \text {, and } 125.1 \\
\text { million inhabitants, respectively (World Bank 2020b). }\end{array}$ \\
\hline $\begin{array}{l}\text { Infrastructure available } \\
\text { (mobile phone penetration) }\end{array}$ & $\begin{array}{l}\text { By 2019, the subscriptions per } 100 \text { inhabitants were } 72.33 \\
\text { (CIA.gov 2021c). }\end{array}$ \\
\hline The rule of law & $\begin{array}{l}\text { According to the Rule of Law index, Pakistan is ranked in the } \\
120 \text { th position out of } 128 \text { countries. Its score is } 0.39 \text {, which means } \\
\text { law enforcement and institutions are feeble, and this country has } \\
\text { serious corruption problems (The World Justice Project 2020). }\end{array}$ \\
\hline Financial literacy & $\begin{array}{l}\text { In } 2015,26 \% \text { of the Pakistani population was financially literate } \\
\text { (World Bank 2020b). }\end{array}$ \\
\hline Banking concentration & $\begin{array}{l}\text { In } 2017,44.1 \% \text { of the market was concentrated in a few banks } \\
\text { (World Bank 2020b). }\end{array}$ \\
\hline Multiculturality & $\begin{array}{l}\text { Pakistan is a very diverse country. There are around seven } \\
\text { different ethnic groups and languages in the same region } \\
\text { (CIA.gov 2021c). }\end{array}$ \\
\hline $\begin{array}{l}\text { Employment to population } \\
\text { ratio }\end{array}$ & $\begin{array}{l}\text { In } 2019 \text {, the pre-pandemic year, the employment rate in Pakistan } \\
\text { was } 50.42 \% \text { (World Bank 2020b). }\end{array}$ \\
\hline $\begin{array}{l}\text { Gross National Income per } \\
\text { capita }\end{array}$ & In 2020, the GNI per capita was USD 1280 (World Bank 2020b). \\
\hline
\end{tabular}


Table 15 presents a synthesized diagnosis of the Pakistani context.

Table 15. Selected indicators regarding financial inclusion in Pakistan.

\begin{tabular}{|c|c|c|c|}
\hline Indicator & 2011 & 2014 & 2017 \\
\hline Account ownership (\% age $15+$ ): & $10 \%$ & $13 \%$ & $21 \%$ \\
\hline Mobile money account $(\%$ age $15+)$ & & $6 \%$ & $7 \%$ \\
\hline $\begin{array}{l}\text { Sent or received domestic remittances through a } \\
\text { mobile phone (\% age } 15+)\end{array}$ & & $1 \%$ & $5 \%$ \\
\hline Credit card ownership (\% age $15+)$ & $1 \%$ & $0 \%$ & $1 \%$ \\
\hline Debit card ownership (\% age $15+)$ & $3 \%$ & $3 \%$ & $8 \%$ \\
\hline Saved at a Financial Institution (\% age $15+)$ & $1 \%$ & $3 \%$ & $6 \%$ \\
\hline
\end{tabular}

Source: own illustration based on the Global Findex Database (Demirgüç-Kunt et al. 2018).

In this country, the financial inclusion indicators are shallow. From 2011 to 2017, the improvement of each indicator has increased but not inclusively. In 2017, only $21 \%$ of adults had a bank account, $7 \%$ a mobile money account, and low other indicators.

The overall financial inclusion in Pakistan is above average among lower-middleincome countries and East and South Asia groups. According to this evaluation, the governmental policies and support and consumer protection environment have improved. The scores for the availability of products and outlets and the infrastructure that supports financial services and products are above average, indicating an improvement compared to lower financial inclusion indicators of the Global Findex Database in 2017.

A summary of every country's environment overview is presented in Appendix A to comprehend the situation of the analyzed countries from a comparative and holistic perspective.

\subsection{Pearson Multivariable Correlation Analyses}

This subsection develops four Pearson multivariable correlation analyses to search if the presence of the FinTech (a) in Country (A__the percentage of the population of Country (A) that is a customer of FinTech (a) - has a linear relationship with the most common and basic financial inclusion indicators studied in Sections 3.2 and 3.3. Table 16 presents the independent and dependent variables.

Table 16. Independent and dependent variables.

\begin{tabular}{|c|c|}
\hline Independent Variable & The Population of Country (A) and User of FinTech (a) \\
\hline \multirow{6}{*}{ Dependent variables } & Account $(\%$ age $15+)$ \\
\hline & Mobile money account $(\%$ age $15+)$ \\
\hline & $\begin{array}{l}\text { 3. Sent or received domestic remittances: through a mobile } \\
\text { phone }(\% \text { age } 15+)\end{array}$ \\
\hline & Credit card ownership (\% age $15+$ ) \\
\hline & Debit card ownership ( $\%$ age $15+$ ) \\
\hline & Saved at a financial institution (\% age $15+)$ \\
\hline
\end{tabular}

Source: own illustration based on data from Global Findex Database (Demirgüç-Kunt et al. 2018).

The purpose of conducting a Pearson correlation analysis is to find if the respective FinTech has a role in financial inclusion in the respective country.

\subsubsection{M-PESA in Kenya}

To analyze if M-PESA has a role in Kenya's financial inclusion, the percentage of the population in Kenya that is M-PESA registered users must have been known. Table 17 illustrates this procedure. 
Table 17. Calculation of population of Kenya that is M-PESA user (\%).

\begin{tabular}{cccc}
\hline Users of Fintech (a) in Country (A) & $\mathbf{2 0 1 1}$ & $\mathbf{2 0 1 4}$ & $\mathbf{2 0 1 7}$ \\
\hline M-PESA Customers (million) & 13.8 & 19.3 & 27.0 \\
The population of Kenya above 15 years (million) & 23.7 & 26.2 & 28.8 \\
The population of Kenya as M-PESA users above 15 years (\%) & 58.23 & 73.66 & 93.75 \\
\hline Source: own illustration based on World Bank database (Pinar Ardic et al. 2011) and Safaricom (2021).
\end{tabular}

After this first simple calculation, the corresponding step is to conduct a multivariable correlation analysis between the independent variable "population of Kenya that is M-PESA user" and the six selected financial inclusion indicators shown in Table 18.

Table 18. Correlation analysis for M-PESA in Kenya.

\begin{tabular}{cc}
\hline & $\begin{array}{c}\text { The Population of Kenya as M-PESA Users } \\
\text { above 15 Years }\end{array}$ \\
\hline The population of Kenya as M-PESA users \\
above 15 years & 1.00 \\
Account (\% age 15+) & 0.91 \\
Mobile money account (\% age 15+) & 0.92 \\
Sent or received domestic remittances through & 0.82 \\
a mobile phone (\% age 15+) & -0.19 \\
Credit card ownership (\% age 15+) & 0.98 \\
Debit card ownership (\% age 15+) & 0.44 \\
\hline Saved at a financial institution (\% age 15+)
\end{tabular}

Source: own illustration.

This analysis indicates a very high correlation of the percentage of the population of M-PESA's customers in Kenya and the ownership of an account, mobile money account, and debit card ownership. Likewise, a high correlation between the independent variable and the percentage of people who sent or received domestic remittances through a mobile phone can be identified.

Considering that this company generates most of its revenue from mass transactions such as transferences and payments, these results make sense.

Regarding the technology applied (SIM toolkit), which initially required the change of old SIM cards, it did not discourage people from registering with M-PESA. This result can indicate that the benefit of accessing financial services was more significant than the hassle and cost of changing a SIM card.

These results also identified a moderate correlation between the independent variable and the percentage of people who saved at a financial institution and a negative correlation with credit card ownership.

This outcome can be explained considering that M-PESA's value proposition, marketing strategy, and revenue stream, in the beginning, were not focused on fostering a savings culture or giving credits. This research found that M-PESA's expansion to banking services such as savings began in 2012 when this company partnered with the Commercial Bank of Africa (Safaricom 2014). Therefore, it will be interesting to analyze this indicator in the upcoming years.

From the demand side, a reason that could explain the low percentage of people who saved at a financial institution remains basically on Kenya's lower financial literacy rate $(38 \%)$ and the low GNI per capita in this country.

Considering that most of the indicators present a positive high and very high correlation, the answer to RQ1 $1_{\mathrm{M}-\mathrm{PESA}}$ is that M-PESA effectively has a role in the financial inclusion in Kenya across many of its dimensions. Hence, $\mathrm{H}_{1} \mathrm{a}_{\text {Kenya }}$ can be confirmed because these results verify that M-PESA positively affects financial inclusion in Kenya, and there will be lessons to be learned from its business model.

After analyzing the results, RQ2 2 -PESA can be answered by describing the lessons learned of the characteristics of M-PESA's business model and country environment. There- 
fore, one of the possible success factors is M-PESA's strategy of focusing on specific essential financial products and targeting masses with simple messages; educating people about the benefits of accessing and using formal financial services; the planned and scaled installation of the agents' network; and engaging with local culture and active agent networking. Moreover, the scaled price structure of one of the services (withdrawals) indicates the lower cost of realizing transactions, which could have had a positive incentive on Kenyans to learn multiple transactions due to the lower costs involved.

The lesson gained regarding the technology applied for M-PESA at the beginning (SMS Toolkit) is its simplicity in delivering essential financial services because it proved to have higher benefits than banking sector services. After all, if installing a new mobile SIM card is cheaper and easier than going to a bank access point, then it is likely that people will decide to obtain a mobile SIM card to realize transactions even from home.

Finally, another characteristic to be observed from the Kenyan environment is the lower concentration of the financial sector, the fewer direct competitors of M-PESA, and a clear regulatory framework that probably fostered the first actions of this company efficiently. However, it was noted that recently the government implemented regulations for lenders and customer protection, which can impact the indicator regarding savings in the future.

\subsubsection{Nubank in Brazil}

Table 19 presents Brazil's Nubank users (the independent variable).

Table 19. Calculation of population of Brazil that is Nubank user (\%).

\begin{tabular}{cccc}
\hline Users of Fintech (a) in Country (A) & $\mathbf{2 0 1 1}$ & $\mathbf{2 0 1 4}$ & $\mathbf{2 0 1 7}$ \\
\hline Nubank Customers (million) & 0.0 & 0.0 & 3.0 \\
The population of Brazil above 15 years (million) & 135.6 & 140.6 & 144.8 \\
The population of Brazil as Nubank users above 15 years (\%) & 0.00 & 0.00 & 2.07 \\
\hline Source: own illustration based on World Bank (World Bank 2016) database and Statista (2021).
\end{tabular}

In this case, a complete evaluation could not be performed due to the lack of data. However, it was possible to find the following with the available data shown in Table 20.

Table 20. Correlation analysis for Nubank in Brazil.

\begin{tabular}{|c|c|}
\hline & $\begin{array}{c}\text { The Population of Brazil as Nubank Users } \\
\text { above } 15 \text { Years }\end{array}$ \\
\hline $\begin{array}{l}\text { The population of Brazil as Nubank users } \\
\text { above } 15 \text { years }\end{array}$ & 1.00 \\
\hline Mobile money account ( $\%$ age $15+)$ & 0.99 \\
\hline Credit card ownership (\% age $15+$ ) & -0.83 \\
\hline
\end{tabular}

Source: own illustration.

From these results, a high correlation between Brazil's population, Nubank users, and the percentage of people who own a mobile money account can be confirmed. However, there is a high negative correlation with the percentage of people who own a credit card. These results can be explained by the lower rate of mobile money accounts in Brazil in 2017 and the increasing popularity and new subscriptions to Nubank in the same year.

Although these results indicate that Nubank has no role in financial inclusion in Brazil, it could be interesting to know the results from 2017 to 2021 . Up to date, Nubank has 40 million customers in Brazil (Statista 2021), which means that this year, 27\% of the population of Brazil older than 15 years is a customer of Nubank. The insufficient data for conducting this correlation analysis made it necessary to search for another similar indicator found in the Brazilian Central Bank database. After retrieving information regarding the change of credit activity of households from 2015 to 2020 (The World Bank 2021), the report was complete for conducting correlation analysis, as shown in Table 21. 
Table 21. Indicators to analyze Brazil (2015-2020).

\begin{tabular}{ccccccc}
\hline Indicators & $\mathbf{2 0 1 5}$ & $\mathbf{2 0 1 6}$ & $\mathbf{2 0 1 7}$ & $\mathbf{2 0 1 8}$ & $\mathbf{2 0 1 9}$ & $\mathbf{2 0 2 0}$ \\
\hline $\begin{array}{c}\text { The population of Brazil as } \\
\text { Nubank users above 15 years (\%) }\end{array}$ & 0.3 & 0.9 & 2.0 & 4.0 & 7.0 & 17.0 \\
\hline $\begin{array}{c}\text { Credit operations (12-month \%) } \\
\text { change households }\end{array}$ & -10.6 & -12.4 & 11.0 & 17.7 & 21.5 & 9.0
\end{tabular}

Source: own illustration based on information collected from the Brazilian Central Bank (World Bank 2020a) and Nubank (Nubank 2021).

The independent variable remains the percentage of the Brazilian population of Nubank customers, and the dependent variable is credit operations (12-month \% change in households). The proportion of Nubank's customers was obtained from Statista, considering the current clients of this company and the total population of Brazil from 2016 to 2020 (Statista 2021). In Table 22, the correlation analysis between these mentioned variables is presented.

Table 22. Correlation analysis for Nubank in Brazil.

The Population of Brazil as Nubank Users above 15 Years $(\%)$

$\begin{array}{lc}\begin{array}{c}\text { The population of Brazil as Nubank users } \\ \text { above } 15 \text { years (\%) }\end{array} & 1.00 \\ \begin{array}{c}\text { Credit operations (12-month \%) change } \\ \text { households }\end{array} & 0.44\end{array}$

Source: own illustration.

This correlation analysis shows a non-significant correlation between customers of Nubank in Brazil and the credit operations in this country. Therefore, the answer to RQ1 $1_{\text {Nubank }}$ is that Nubank does not have a significant role in financial inclusion in Brazil. Hence, $\mathrm{H} 1_{\text {Brazil }}$ is confirmed because after conducting these correlation analyses, the results indicate that Nubank does not have a role in financial inclusion in Brazil.

After analyzing the results, $R Q 2_{\text {Nubank }}$ can be answered by identifying factors that impeded the impact of Nubank on financial inclusion in Brazil. These factors could be the high banking concentration, lower employment rate despite a middle-high GNI per capita, and lower financial literacy rates. Additionally, Brazil's extensive territory and population are concentrated in large cities, and being culturally diverse, among other factors, could have harmed financial inclusion in this country, making it difficult for companies to provide mobile money solutions to people living in remote areas who speak another language.

What is remarkable about Nubank is its ability to challenge a high concentrated market by providing no fees, fast, easy, and convenient $100 \%$ digital financial services. The value proposition and the revenue stream of this start-up ensured its rapid growth and its positive revenue in the year 2020, during the COVID-19 crisis, indicates that Nubank is positioning in the Brazilian financial sector, and it will be interesting to analyze if in the upcoming years this company will have an impact on financial inclusion in Brazil.

\subsubsection{GCASH in the Philippines}

Table 23 presents how the percentage of the population in the Philippines that is GCASH users was calculated. 
Table 23. Calculation of population of the Philippines as GCASH user (\%).

\begin{tabular}{cccc}
\hline Users of Fintech (a) in Country (A) & $\mathbf{2 0 1 1}$ & $\mathbf{2 0 1 4}$ & $\mathbf{2 0 1 7}$ \\
\hline GCASHCustomers (million) & 1.3 & 3.0 & 5.1 \\
The population of the Philippines above 15 years (million) & 59.4 & 63.2 & 66.9 \\
The population of the Philippines as GCASH users above 15 years (\%) & 2.19 & 4.75 & 7.62 \\
\hline Source: own illustration based on World Bank database (World Bank 2020d) and Globe (GLOBE 2014; GLOBE
\end{tabular}
2017).

Table 24 presents the multivariable correlation analysis for GCASH in the Philippines to determine if this company has a role in financial inclusion in this country.

Table 24. Correlation analysis for GCASH in the Philippines.

\begin{tabular}{cc}
\hline & $\begin{array}{c}\text { The Population of the Philippines as } \\
\text { GCASH Users above 15 Years }\end{array}$ \\
\hline The population of the Philippines as GCASH & 1.00 \\
users above 15 years & 0.99 \\
Account (\% age 15+) & 0.88 \\
Mobile money account (\% age 15+) & 0.79 \\
Sent or received domestic remittances through & -0.87 \\
a mobile phone (\% age 15+) & 0.88 \\
Credit card ownership (\% age 15+) & -0.87 \\
Debit card ownership (\% age 15+) & \\
\hline
\end{tabular}

Source: own illustration.

The results indicate a very high correlation of the independent variable (Population of the Philippines and GCASH users) and the dependent variable account ownership. Likewise, a high correlation is visible with the following variables: mobile money account, sent or received domestic remittances, and debit card ownership. There are two high negative correlations with the variables: credit card ownership and savings at a financial institution.

The high coefficient correlations obtained make sense because GCASH generates most of its revenue from remittances, payments, deposits, withdrawals, purchases, and others easily realized through mobile money accounts, bank accounts, and debit cards.

The results obtained indicate that the strategy of this company to deliver its value proposition was successful because it gained customers constantly in the studied period, and it has expanded its customer base even during the COVID-19 crisis (from 1.3 million customers in 2011 to 33 million in 2021). Therefore, it is logical that GCASH impacts these dimensions of financial inclusion in the Philippines.

From the demand side, the obtained results make sense because the constant growth of this country's population, high mobile phone subscriptions, and increasingly middle-class population (GNI per capita USD 3530 in 2017) facilitate consumption and encourage saving habits there is a need to circulate money. This overall situation is optimal for a provider of mobile money services, such as GCASH.

The Philippine environment contributes to the results because the complex geography conditions of this archipelagic country and the weak institutions and law enforcement discourage the traditional banking sector from building branches or access points. Therefore, where traditional banks do not have incentives to expand, mobile money operators have a lower risk of offering essential financial services.

The results present that GCASH has a high negative correlation coefficient with the percentage of people who saved at a financial institution and credit card ownership. This outcome makes sense because, differently from M-PESA, G-CASH did not apply educational content in its marketing campaigns nor a strategy that brings together the different ethnic groups in this country. Furthermore, the lack of know-how of the banking 
sector could influence this negative outcome. Again, from the environment side, these negative coefficient correlation results make sense because financial literacy in this country is weaker than in Kenya, indicating the limited knowledge of fundamental financial aspects such as the benefits of saving, the calculation of interest rates, or how to avoid overindebtedness.

After evaluating the results, and overall positive correlation was found with most dependent variables. The answer to RQ1 $1_{\mathrm{GCASH}}$ is that GCASH has a role in financial inclusion in the Philippines across many dimensions. Hence, H1 $\mathrm{a}_{\text {Philippines }}$ can be confirmed because these results verify that GCASH positively affects financial inclusion in the Philippines, and there will be lessons to be learned from its business model.

After analyzing the results, $\mathrm{RQ} 2_{\mathrm{GCASH}}$ can be answered by describing the lessons learned of the characteristics of the business model and country environment of GCASH. Therefore, one of the possible success factors is GCASH's initial strategy by delivering its value proposition - facilitate mobile money transactions through prepaid credit—via the system created by Globe telecom and the agent points, without the participation of banks. This initial approach could have given the company the flexibility to provide services that the traditional financial sector managed.

Regarding the lower correlations with credit cards and services, an important lesson to be learned is the importance of alliances with banks to expand the provision to traditional financial services such as savings accounts, credit cards, and others due to the exclusive know-how that banks possess, which could complement the innovative technologies that a FinTech provides. Nonetheless, the outcome of alliances with banks to offer other types of financial services such as borrowings or investments should be analyzed in the upcoming years after GCASH has adapted its business model and value proposition to the new products and services provided.

Likewise, in M-PESA's case, an important lesson is to service technology easy to adapt and obtain. The SIM Toolkit technology requires changing the original SIM card. Still, when the benefits and conveniences to the users are more significant than accessing traditional banking access points, people will likely decide to obtain a mobile SIM card to make transactions from home.

\subsubsection{Easypaisa in Pakistan}

Table 25 presents the calculation of the percentage of the population in Pakistan as Easypaisa users, which is the independent variable.

Table 25. Calculation of population of Pakistan as Easypaisa user (\%).

\begin{tabular}{lccc}
\hline \multicolumn{1}{c}{ Users of Fintech (a) in Country (A) } & $\mathbf{2 0 1 1}$ & $\mathbf{2 0 1 4}$ & $\mathbf{2 0 1 7}$ \\
\hline Easypaisa Customers (million) & 2.0 & 6.0 & 19.9 \\
The population of Pakistan above 15 years (million) & 107.1 & 116.1 & 125.2 \\
The population of Pakistan as Easypaisa users above 15 years (\%) & 1.87 & 5.17 & 15.89 \\
\hline Source: own illustration based on World Bank database (World Bank 2020d) and Globe (GLOBE 2014; GLOBE \\
2017).
\end{tabular}

The obtained data are used to conduct the multivariable correlation analysis that aims to understand the relationship between the independent variable and the financial inclusion indicators for this country. In Table 26, the results are presented.

The results indicate a very high coefficient correlation of the independent variable and most of the dependent variables, such as account ownership and the percentage of people who sent or received domestic remittances through mobile phones, debit card ownership, and savings at a financial institution. There is a high coefficient correlation with the variable mobile money accounts and a moderate correlation with credit card ownership.

The overall outcome of the correlation analysis indicates that despite Easypaisa's influence on financial inclusion in Pakistan, most of the Pakistani population in 2017 did not have access to financial services. Nevertheless, the high and positive coefficient 
correlations could indicate that Easypaisa strives to reach more customers. Still, the entire environment of the country and the demand side factor is not optimal.

Table 26. Correlation analysis for Easypaisa in Pakistan.

\begin{tabular}{cc}
\hline & $\begin{array}{c}\text { The Population of Pakistan as Easypaisa } \\
\text { Users above 15 Years }\end{array}$ \\
\hline The population of Pakistan as Easypaisa users \\
above 15 years & 1.0000 \\
Account (\% age 15+) & 0.9999 \\
Mobile money account (\% age 15+) & 0.7819 \\
Sent or received domestic remittances through & 0.9981 \\
a mobile phone (\% age 15+) & 0.5695 \\
Credit card ownership (\% age 15+) & 0.9769 \\
Debit card ownership (\% age 15+) & 0.9846 \\
\hline Saved at a financial institution (\% age 15+)
\end{tabular}

Source: own illustration.

Back to the correlation analysis, it was found that Easypaisa, in contrast to M-PESA and GCASH, strongly influences the percentage of people who saved at a financial institution and has a moderate influence on credit card ownership. This result is remarkably different because M-PESA and GCASH did not influence those products.

Since the results indicate an overall positive high and very high correlations, the answer to RQ1 Easypaisa is that Easypaisa has an essential role in the financial inclusion in Pakistan in many of its dimensions. Hence, H1a Pakistan can be confirmed because these results verify that Easypaisa positively affects financial inclusion in Pakistan, and there will be lessons from its business model.

After analyzing the results, RQ2 ${ }_{\text {Easypaisa }}$ can be answered by describing the lessons learned of the characteristics of Easypaisa's business model and country environment. One of the possible success factors of this company is the original partnership by Telenor and Tameer Microfinance Bank because it provided this company's value proposition enough know-how to design various financial products.

Therefore, the lesson to be learned from Easypaisa's strategy is the critical value that financial institutions contribute to FinTech regarding the know-how of typical and traditional financial services and products. This reason probably influences Easypaisa's higher impact on credits and savings. Furthermore, the strategy applied by adapting their products to people's needs and investing in high-quality and educative advertisements is probably some of the additional reasons for the high impact of Easypaisa on Pakistani financial inclusion.

Another success factor could have been the scaled price structure of one of Easypaisa's services. In the example of withdrawals, the cost involved in making this transaction is meager. Like M-PESA and GCASH, the prices are affordable for all population sectors. Therefore, the access and usage of Easypaisa's system increased over the years. Nonetheless, a large population sector is still excluded from these services.

The lesson gained regarding the technology applied for Easypaisa (USSD menu encryption) to deliver essential financial services requires learning the mobile's menu options to send and receive money through agents. Unlike M-PESA and GCASH, this approach did not require changing the SIM card. Indeed, it was a success factor because if learning a mobile-based program is cheaper and easier than going to a bank access point, people will likely decide to learn this program.

\section{Discussion: Lessons for Peruvian Financial Inclusion}

After analyzing the role of each studied company in financial inclusion in their respective countries, several lessons were learned for the Peruvian situation. The Peruvian context in 2017 reported shallow indicators in financial inclusion, which can be explained due to the complicated geographical conditions that exclude remote areas in the Andes and 
the jungle. Moreover, the population is highly concentrated in the big cities, which creates incentives for mobile operators and banks to attend to the demand in these big cities.

The demand side found that the GNI per capita is USD 6010, with higher employment rates and high mobile phone subscriptions per 100 inhabitants (123.7). Therefore, it could be said that any mobile money operator would have significantly impacted financial inclusion if the optimal conditions for this type of project were given.

Furthermore, it could be assumed that multiculturality, language diversity, and lower financial literacy could not be determinant barriers to mobile money operators. In countries such as Kenya, the Philippines, and Pakistan, these factors did not impede the expansion of mobile money operators. This specific situation can be part of a deeper study, but this exploratory research indicates that other companies had success despite similar unfavorable conditions.

From the supply side, the most crucial observation is the high banking concentration in this country $(72.7 \%)$. This indicator implies high barriers for competitors to enter this market.

Nevertheless, there are lessons that the studied cases have provided. Firstly, the need for partnerships between banks and FinTechs because both companies complement their value proposition to be delivered properly. Bim's approach and the existing mobile wallets can likely disrupt financial inclusion in Peru. A future study can confirm this hypothesis when there are enough public data. Nonetheless, regulation incentives must orient companies to facilitate the access and usage of financial services and not fight for market share.

Secondly, FinTechs and banks should conduct marketing strategies with a highly educational message that reaches all the population and engages with local culture. As observed in the case of M-PESA and Easypaisa, this strategy creates confidence and incentives for people to access and use financial services.

Thirdly, the low cost of the charges to each transaction is one of the most important aspects because the benchmarking realized was compared three hypothetical transactions and the respective charges. In Table 27, the details are presented.

Table 27. Comparison price structure of withdrawals.

\begin{tabular}{cccc}
\hline & M-PESA & CASH & EASYPAISA \\
\hline \multirow{2}{*}{ Withdrawal amount } & (KES) 100-500 & (PHP) 200 & (PKR) 500-1000 \\
& (EUR) 0.77-3.87 & (EUR) 3.39 & (EUR) 2.56-5.12 \\
Charge & (KES) 27 & (PHP) 4 & (PKR) 20 \\
& (EUR) 0.21 & (EUR) 0.068 & (EUR) 0.1 \\
\hline
\end{tabular}

Source: own illustration based on M-PESA (Safaricom 2021), Globe (GLOBE 2014; GLOBE 2017), and Easypaisa (Easypaisa 2021b).

The price of each transaction is considerably low compared to the amount withdrawn. In this case, Peruvian FinTechs can pursue a lower cost to gain users due to the high banking concentration and high competition.

Finally, the technology to be applied must be easy to use and understand for all types of users, whether poorer or wealthier. Therefore, the SIM Toolkit and USSD technologies should be available for all mobile operators because these technologies have proven to facilitate mobile money transactions. Thus, smartphone applications can discourage the poorer sectors of the population from accessing BIM or other mobile wallets since all population segments cannot afford the cost associated with a smartphone.

\section{Conclusions}

This research began by questioning how Peru could improve its financial inclusion indicators to help its population access and use formal financial services to enhance their lives prevent the COVID-19 or any other virus transmission, and efficiently provide financial help to vulnerable families unbanked. It was necessary to learn and comprehend 
essential concepts such as financial inclusion and efficient methods to answer this problem statement.

Financial inclusion understood as a market failure in which supply, demand, and country environment forces play a role, is the most accurate approach developed by the literature because that is how the problem of financial exclusion can be addressed and measured by policymakers, financial institutions, and relevant stakeholders on this matter. Additionally, through this approach, it is possible to comprehend financial inclusion as a multidimensional topic that requires further and deeper studies that allow policymakers and Governments to formulate and apply adequate measures to achieve high access and usage of formal financial services in developing countries.

In 2004, 2008, 2009, 2013, respectively, GCASH, M-PESA, Easypaisa, and Nubank were launched. These FinTechs specialized in providing mobile money services disrupted the financial sector in their respective countries thanks to their business models and value propositions. Consequently, a comprehensive analysis of these companies and their respective governments could provide lessons for countries with lower financial inclusion indicators and started after these companies-for example, Peru.

The country analysis of Peru has shown a favorable environment for launching one or many mobile money services because this country is expected to recover rapidly after the COVID crisis, increasing consumption and employment rates. Moreover, more than 100 mobile subscriptions per 100 inhabitants indicate that the demand in Peru is ready to meet the supply of mobile money services. Nonetheless, the Global Findex Database (Demirgüç-Kunt et al. 2018) showed that Peruvian indicators of account ownership, savings, credit and debit cards, sending remittances, and mobile money account were very shallow.

There are many reasons why financial inclusion in Peru is very low. The proximity of the access points to the population affects the usage of bank accounts and credits because of the transportation time to the access point for making transactions. Therefore, the probability of obtaining informal credits is higher. In addition, Peru is a middle highincome country with a GNI per capita of approximately USD 6010. However, people usually have an improved economic position in Lima and big cities in the capital city. In contrast, the people who live in the remote areas in the Andes and the Jungle do not have the same economic condition. Therefore, the lower ability to pay decreases the access to formal credits. The usage of financial services in Peru depends on the value that the populations assign to it. If the population does not perceive the value of products, they are not adequate to their needs and capacities or lack knowledge of the actual products. Therefore, the government and the financial sector must improve financial literacy and confidence in the financial industry. An essential factor in Peru is that the financial industry provides services in the majoritarian language in Peru without considering the country's language and cultural diversity. It is difficult to access and use products and services that are not provided in the native language of some sectors of the population, for example, Quechua and Aymara.

Global Microscope (Economist Intelligence Unit 2019) provides an overall financial score after assessing the enabling environment for financial inclusion. In this study, Peru achieves a high overall financial inclusion score, surpassing peer countries in Latin America and the Caribbean and upper-middle-income countries due to government support, market stability and integrity, excellent products and outlets, and better-quality consumer protection rules and infrastructure. The recent better scores for Peru can also be influenced by the fast measures introduced by the government in response to the COVID-19 emergency by facilitating e-money, ease of credit for microfinance institutions, emergency cash transfer through a bank account or cellular account with the Bank of the government (Banco de la Nacion), or in cash at a designated agent. Moreover, the government launched special funds for entrepreneurs and farmers to develop micro insurances, factoring, and leasing to improve financial inclusion for micro-enterprises and other small businesses.

Analysis of Kenya, Brazil, the Philippines, and Pakistan enables the following conclusions: 
- The overall financial inclusion score of Kenya is above the average in the region and the group of lower-middle-income peers. The government and policy support, market stability and integrity, and consumer protection rules and infrastructure have an above-average score, indicating that this country's financial inclusion environment is favorable. However, the dimension of products and outlets indicates challenges because the score obtained locates Kenya far under average peer countries in SubSaharan Africa and lower-middle-income countries. In 2020, during the COVID-19 crisis, the Central Bank of Kenya applied liquidity measures to financial institutions to support borrowers affected by the pandemic. Financial institutions could also extend and restructure loans for incapable borrowers to pay due to the pandemic. The Central Bank of Kenya introduced measures to increase the use of mobile money by removing transactions fees for transfers between mobile money accounts and bank accounts. The Kenyan government implemented money transfer programs through traditional bank accounts and M-PESA to alleviate the needs of households. These programs provided monthly financial help to around 1.1 million beneficiaries.

- Brazil has achieved an important number of account holders and debit cardholders. Nevertheless, the mobile money account, domestic remittances, and saving culture remains in a meager percentage. The high rate of people who own bank accounts and debit cards can be due to the integrated efforts of the Brazilian government, the Central Bank of Brazil, and stakeholders to promote financial inclusion in this country. These efforts were continued in 2019 by the Central Bank of Brazil, which launched a work plan focused on technological evolution to resolve structural problems in the financial system, competitiveness, transparency, and education. Mobile money accounts, savings, and remittances are not popular in this country, probably because of the lack of trust in the financial sector, lack of money, or lower financial literacy rates. The financial sector's main problems in Brazil are the lack of bank branches and service points, especially in small rural areas, high documentation requirements to open bank accounts, high costs associated with bank accounts, and high-interest rates for credits. The response of the Brazilian government regarding the COVID-19 crisis was to increase liquidity in the financial system and a temporary relaxation of provisioning rules. The Central Bank opened a facility to provide loans to financial institutions, and the five largest banks in the country agreed to provide individuals and SMEs 60 day extension of debts. Likewise, the authorities offered temporary income support to vulnerable households, such as cash transfers to informal and low-income people. Brazil's overall financial inclusion score is superior to the average in Latin American and Caribbean countries and the group of upper-middle-income countries. It could be said that this positive outcome in 2020 was due to efforts of the government, the Central Bank, and the financial sector of Brazil.

- The Central Bank of the Philippines (BSP) and the government are significant players creating regulations regarding financial inclusion. In 2009, the BSP created an electronic money ecosystem and efficient retail payments platform to allow banks to develop partnerships with e-money service providers such as telecommunication companies or become e-money issuers, either directly or through partnerships. In 2010, BSP enabled a regulatory environment to create a platform for electronic money and the expansion of financial access points through micro-banking offices, and in 2012 it was issued a regulation to ensure consumer protection. The indicators of financial inclusion in the Philippines are low. Account and debit card ownerships represent a higher percentage, showing progress through the years. However, the other indicators remain low. These results indicate an essential gap to provide suitable financial products and services to the population's needs. Since 2016, a governmental institution has been created that guides and oversees the implementation of the National Strategy for Financial Inclusion, which places particular focus on digital financial inclusion and financial and digital literacy. However, an important issue was ensuring interoperability in retail payments because of the limited number of operators and the high transaction 
costs. The outlook of financial inclusion in the Philippines is promising since this country was recognized in 2016 as an ideal place for developing digital and financial products and services due to its large young population, positive annual GDP growth, fast-growing internet penetration, and mobile phone engagement. The creators Smart Money and GCASH approached this market in new ways. The overall financial inclusion score is higher than peers in East and South Asia and higher than in lowermiddle-income countries. This outcome is a positive sign that the measures introduced by authorities since 2016 may have provided better governmental and policy support, stability to the financial system, and consumer protection rules. Therefore, the supply of products and services has increased, and this country's overall financial inclusion situation has improved. However, there are still gaps to improve, especially regarding implementing adequate infrastructure to connect this country's remote rural and low populated areas.

- In Pakistan, the financial inclusion indicators are shallow. Mobile account penetration remained extremely low despite the significant growth observed in mobile account activity. The challenge of expanding mobile money account users is linked to customer education on financial services. This indicator increased only 1\% from 2014 to 2017, which means that the regulation implemented by the State Bank of Pakistan was not enough to encourage the market of mobile money services to develop further. In 2015, the Pakistani government established a National Financial Inclusion Strategy, which in 2018 was modified to place more emphasis on promoting digital payments to increase the number of digitized accounts. In addition, the State Bank of Pakistan (the Central Bank) implemented reforms in 2019 to allow non-banking entities to issue e-money directly. With this new regulation, mobile operators can provide further product innovations in digital finance. The COVID-19 pandemic hit this country's economy due to lockdown measures to contain the spread of the virus. Therefore, the State Bank of Pakistan launched relief and stimulus measures to ensure adequate liquidity in the financial system, allowing Banks to defer the repayment of loans, and stimulating banks to keep lending small and medium enterprises to support the businesses in the country. Other measures introduced were promoting digital banking by waiving all fees for online transfers. To alleviate the most vulnerable population, the State Bank of Pakistan launched an emergency cash transfer program accessible after an online application and a confirmation received via SMS. The funds were targeted and delivered to female heads of households. The overall financial inclusion in Pakistan is above average among lower-middle-income countries and in the East and South Asia groups. The governmental policies and support and consumer protection environment have improved. The scores for the availability of products and outlets and the infrastructure that supports financial services and products are above average, indicating an improvement in comparison to lower indicators of financial inclusion.

After analyzing each company in its respective country, the qualitative assessment did not reveal information about its performance regarding financial inclusion in the respective region because financial inclusion is a multidimensional study topic that requires deep and extensive study of diverse factors. Therefore, only after conducting multivariable correlation analysis was realized that all studies provided relevant information on each company's financial inclusion performance in the respective country.

Consequently, insightful and exciting results were found, proving that despite the remarkable stories of M-PESA and GCASH, these companies specialized in mobile money transfers and payments. Still, they could not provide financial services such as savings and credit card ownership. Their recent partnerships with banks realized that expanding the supply of various financial assistance due to the know-how of financial institutions can prove in the future if the influence of banks is determinant to achieve high rates of financial inclusion in a country. 
The case of Easypaisa is from a business model perspective very similar to GCASH and M-PESA. However, the main difference is that this company began its activities influenced by a FinTech and a Microfinance Bank. Overall financial inclusion indicators for Pakistan are shallow. Nevertheless, the impact of Easypaisa on all the selected indicators is positive, which may indicate the importance of the participation of banks in these operations, despite the downsides of managing two different business structures (bank and FinTech).

Comparatively, the costs of making withdrawals in M-PESA, GCASH, and Easypaisa are meager. Each company implements charges according to the withdrawal strategy that helps to make a profit out of small millions of transactions. The case of Nubank is entirely different since the original product is a credit card with no fees, which provides revenue to the company through charges to exchange rates, charges for payment of bills, and penalties of overdue payments.

The case of Nubank is fascinating because the FinTech start-up challenges banks in a country such as Brazil, which has produced a highly concentrated financial sector within a few years. Moreover, the company expanded to provide other financial services, such as mobile money accounts, remittances, and insurances. Future research regarding the impact of Nubank on financial inclusion in Brazil could be done by considering updated data after 2017, the year in which the company scaled speedy upwards.

Appendix B summarizes and presents each company's business model comparatively to provide a holistic comprehension of each selected company.

The Peruvian context can learn from all the cases analyzed since its financial inclusion indicators are low and the geographical, cultural, and educational difficulties are barriers to reaching remote areas. However, after analyzing all presented cases, the main difference is that Peru has the highest bank concentration among the studied countries. Therefore, it would be desirable that banks have incentives aligned to create a financially included system before their interest in market share. A proper regulation that facilitates responsible participation of FinTechs competing with banks can challenge the status quo. It could create a desired competitivity that expands financial services to the most remote areas.

Furthermore, regarding the technology applied, it must be considered that not all sectors of the Peruvian population can afford to have a smartphone. Therefore, efforts must be made to ensure the availability and feasibility of the SIM toolkit or USSD technology to facilitate mobile money transactions. Additionally, the price structure must be the lowest possible to compete with banks' mobile wallets and BIM.

This study provided several insights about financial inclusion and how mobile money solutions impact financial inclusion. Therefore, the entire topic of mobile money products and services offers the possibility to further research specific areas, such as assessing the impact of technologies SIM Toolkit and USSD on financial inclusion, because, in this study, it was learned that both technologies are different (the second is more accessible than the first one) but had the same impact.

With recent data, it would be interesting to study the impact of the mobile wallet BIM on financial inclusion in Peru after 2017, analyzing whether banks' mobile wallets or BIM significantly impact the Peruvian financial inclusion situation.

Likewise, future research can be conducted to analyze the impact of COVID-19 on financial inclusion in the selected countries for this study because, in the literature and data review, the pandemic created a triggering effect that conducted people to mobile money services. Additionally, it would be attractive to assess if the access and use of mobile money services remain evenly after the pandemic.

Since banks played an essential role in most selected FinTechs, future research can analyze and determine the optimal functions FinTechs and banks must perform to provide financial services that address customers' needs.

The practical implications of this research can help FinTech startups in Peru that have a primary purpose of reaching the unbanked. Based on the experience of other countries, it will be possible to understand how other companies faced, almost two decades ago, the same challenges in a similar environment. They strived to reach the unbanked by 
generating profit. Therefore, it will be possible for new FinTechs to anticipate factors that have already happened in other countries.

Additionally, banks can understand the risk of the entrance of new players that can place their market share under stress. Therefore, a proper understanding of how other companies handled similar situations can open collaborations with FinTechs to reach the unbanked.

Policymakers understand that regulation plays a vital role as a barrier to new entrants and as a tool for customer protection. Therefore, a proper balance must be analyzed to provide adequate incentives for FinTechs, the financial sector, and customers.

Author Contributions: Conceptualization, V.B. and P.V.V.; methodology, V.B. and P.V.V.; software, T.H.; validation, R.K.V. and T.H.; formal analysis, P.V.V.; investigation, P.V.V.; resources, V.B.; data curation, T.H.; writing—original draft preparation, P.V.V.; writing—review and editing, R.K.V.; visualization, T.H. and Romana Horvat Vode; supervision, V.B.; project administration, Tatjana Hprvat; funding acquisition, R.K.V. All authors have read and agreed to the published version of the manuscript.

Funding: This research received no external funding.

Informed Consent Statement: Not applicable.

Data Availability Statement: Not applicable.

Conflicts of Interest: The authors declare no conflict of interest. 


\section{Appendix A}

Table A1. Benchmarking of country's environment for financial inclusion.

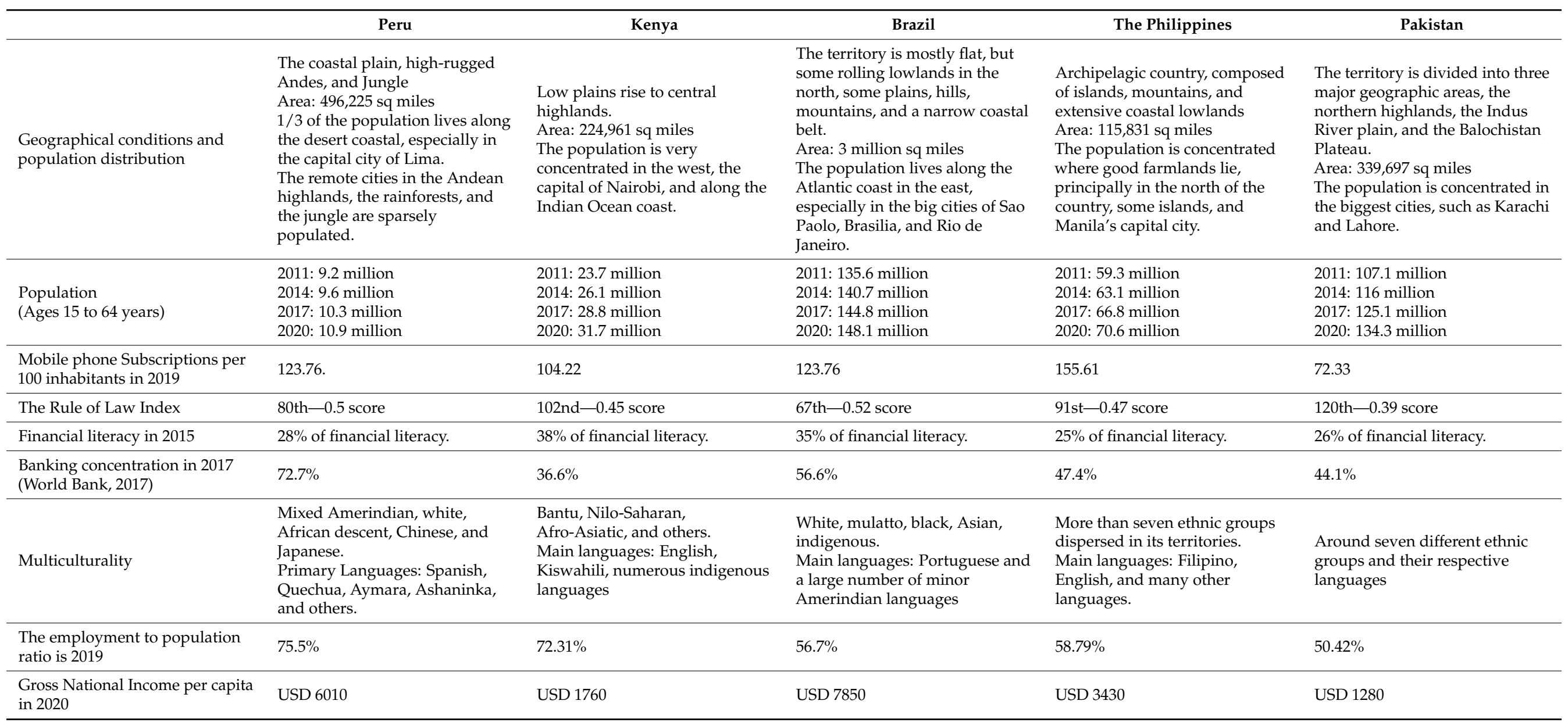




\section{Appendix B}

Table A2. Benchmarking of Remarkable FinTechs' business model.

\begin{tabular}{|c|c|c|c|c|}
\hline & M-PESA & Nubank & GCASH & Easypaisa \\
\hline $\begin{array}{l}\text { Business } \\
\text { objective }\end{array}$ & $\begin{array}{l}\text { Deliver a simple, fast, safe, and easy method } \\
\text { to move money across the country. }\end{array}$ & $\begin{array}{l}\text { Provide a credit card service, } 100 \% \text { digital, } \\
\text { without annuities and fees (cheap), fast and } \\
\text { convenient. }\end{array}$ & $\begin{array}{l}\text { Transform the user's phone to a mobile account, } \\
\text { safely, convenient, cheap }\end{array}$ & $\begin{array}{l}\text { Empower people by providing timely, reliable, } \\
\text { flexible, and easy methods of realizing mobile } \\
\text { money transactions. }\end{array}$ \\
\hline Target market & $\begin{array}{l}\text { Bottom of pyramid approach. } \\
\text { They are taking advantage of Safaricom's } \\
\text { large customers base. }\end{array}$ & $\begin{array}{l}\text { In the beginning, Nubank targeted } \\
\text { "millennials" under } 36 \text { years old. } \\
\text { After popularity, the target is people of all } \\
\text { ages and the unbanked. }\end{array}$ & $\begin{array}{l}\text { Bottom of the pyramid, especially young urban } \\
\text { consumers familiar with social media. }\end{array}$ & Bottom of the pyramid and urban population. \\
\hline $\begin{array}{l}\text { Marketing } \\
\text { strategy }\end{array}$ & $\begin{array}{l}\text { Customer education and aggressive } \\
\text { advertisement through all channels and } \\
\text { creating engagement with local culture } \\
\text { Message: "send money home." }\end{array}$ & $\begin{array}{l}\text { The network effect of engaged customers. } \\
\text { Creation of brand awareness through digital } \\
\text { channels and gifting souvenirs in events } \\
\text { Message: obtain financial control quickly. }\end{array}$ & $\begin{array}{l}\text { Humor and colorful ads on TV, internet, and } \\
\text { printed announces } \\
\text { Message: a cheap, fast, accessible, and easy method } \\
\text { to send remittances. }\end{array}$ & $\begin{array}{l}\text { High-quality ads focus on customer education } \\
\text { about the product. } \\
\text { Message: reliable, easy, and convenient } \\
\text { method to realize payments. }\end{array}$ \\
\hline $\begin{array}{l}\text { Revenue } \\
\text { streams }\end{array}$ & $\begin{array}{l}\text { Principally, mobile money transfers and } \\
\text { payment services. } \\
\text { The company had profit during COVID-19. }\end{array}$ & $\begin{array}{l}\text { Interchange fees on every transaction made } \\
\text { with the credit card, taxes over bills, and } \\
\text { invoices not pated when due. }\end{array}$ & $\begin{array}{l}\text { Fees are charged to deposits, withdraws, purchases, } \\
\text { credit penalties, bill payments, bank accounts, and } \\
\text { dormancy fees. }\end{array}$ & $\begin{array}{l}\text { Transferences fees, bill payments, and mass } \\
\text { disbursements. }\end{array}$ \\
\hline Transactions & $\begin{array}{l}\text { Withdrawals, Transferences, } \\
\text { Deposits, registration, buying airtime, } \\
\text { balance inquiry, and change of M-PESA PIN. }\end{array}$ & $\begin{array}{l}\text { Purchases, transferences, bill payments, } \\
\text { withdrawals, salary disbursements, online } \\
\text { shopping, mobile credit recharges, and more. }\end{array}$ & $\begin{array}{l}\text { Payments, transfers, withdrawals, mobile credit } \\
\text { recharge, investment on funds, book movies, shop } \\
\text { online, plant trees, and obtain insurance. }\end{array}$ & $\begin{array}{l}\text { Payments, P2P transfers, mobile credit } \\
\text { recharge credits, savings, remittances, salary } \\
\text { disbursements, and savings products } \\
\text { combined with insurances. }\end{array}$ \\
\hline Main products & $\begin{array}{l}\text { Wealth management, mobile banking, } \\
\text { mobile wallet, credit, and insurances. }\end{array}$ & $\begin{array}{l}\text { Digital bank, credit cards, personal loans, } \\
\text { and insurances. }\end{array}$ & Investment funds, mobile wallets, insurances. & $\begin{array}{l}\text { Mobile banking, various products, and } \\
\text { insurances. }\end{array}$ \\
\hline Users & $\begin{array}{l}\text { In 2021: } 28.21 \text { million customers. } \\
\text { In 2017: } 27 \text { million } \\
\text { In 2014: } 19.3 \text { million } \\
\text { In 2011: } 13.8 \text { million }\end{array}$ & $\begin{array}{l}\text { In 2021: } 40 \text { million customers. } \\
\text { In 2017: } 3 \text { million }\end{array}$ & $\begin{array}{l}\text { In 2021: } 33 \text { million customers. } \\
\text { In 2017: } 5.1 \text { million } \\
\text { In 2014: } 3 \text { million } \\
\text { In 2012: } 1.3 \text { million }\end{array}$ & $\begin{array}{l}\text { In 2021: } 30 \text { million customers. } \\
\text { In 2017: } 19.9 \text { Million } \\
\text { In 2014: } 6 \text { Million } \\
\text { In 2012: } 2 \text { Million }\end{array}$ \\
\hline
\end{tabular}


Table A2. Cont.

\begin{tabular}{|c|c|c|c|c|}
\hline & M-PESA & Nubank & GCASH & Easypaisa \\
\hline $\begin{array}{l}\text { Technology } \\
\text { applied }\end{array}$ & $\begin{array}{l}\text { SIM Toolkit (STK) with SMS delivery for } \\
\text { delivering mobile money transactions. } \\
\text { Smartphone application. }\end{array}$ & $\begin{array}{l}\text { Smartphone app } \\
\text { Own software program and data science. } \\
\text { Partnership with Ripple Net (Blockchain } \\
\text { infrastructure) }\end{array}$ & $\begin{array}{l}\text { SIM Toolkit with SMS usage. } \\
\text { Smartphone app. }\end{array}$ & $\begin{array}{l}\text { USSD mobile money option and at the agent } \\
\text { transactions. Smartphone application. }\end{array}$ \\
\hline Competitors & Airtel Money and T-Kash. & $\begin{array}{l}\text { Banks: Caixa Econômica, Itaú Unibanco, } \\
\text { Bradesco, and Santander. } \\
\text { FinTechs: Digio, Neon, and Intermedium }\end{array}$ & Smart Money, Paymaya, Coins PH, GrabPay, etc. & Omni, Mobicash Timepey \\
\hline
\end{tabular}




\section{References}

Amidžić, Goran, Andre Massara, and Alexander Mialon. 2014. Assessing Countries' Financial Inclusion Is Standing-A New Composite Index. International Monetary Fund. Working Paper. Available online: https://www.imf.org/external/pubs/ft/wp/ 2014/wp1436.pdf (accessed on 13 April 2021).

Atkinson, Adele, and Flore-Anne Messy. 2013. Promoting Financial Inclusion through Financial Education: Oecd/Info Evidence, Policies, and Practice. OECD Publishing. OECD Working Papers on Finance, Insurance, and Private Pensions. Available online: https: / / www.wsbi-esbg.org/SiteCollectionDocuments /OECD\%20Promoting\%20financial\%20inclusion\%20through\% 20financial\%20education.pdf (accessed on 13 July 2021).

Banco Central do Brasil. 2021. Conglomerado prudencial e instituiçõnes independentes: Resumo. Banco Central do Brasil. Available online: https:/ / www3.bcb.gov.br/ifdata/\# (accessed on 28 July 2021).

Bank for International Settlements. 2020. Payment Aspects of Financial Inclusion in the Fintech Era. World Bank. Bank for International Settlements. Committee on Payments and Market Infrastructures (CPMI). Available online: https://www.bis.org/cpmi/publ/d1 91.pdf (accessed on 28 July 2021).

Barajas, Adolfo, Thorsten Beck, Mohamed Belhaj, and Sami Ben Naceur. 2020. Financial Inclusion: What Have We Learned So Far? What Do We Have to Learn? International Monetary Fund. Working Paper. Available online: https://www.google.com/url? $\mathrm{sa}=\mathrm{t} \& \mathrm{rct}=\mathrm{j} \& \mathrm{q}=\& \mathrm{esrc}=\mathrm{s} \&$ source=web\&cd=\&ved=2ahUKEwiCyu6_yc7tAhUGNOwKHRjrCoMQFjASegQIIBAC\&url=https\%

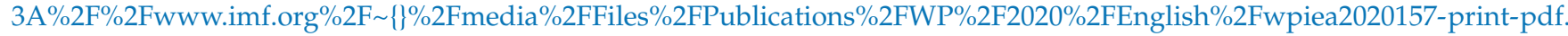
ashx\&usg=AOvVaw3UcfdNtM0iibhAbH_ni3Ji (accessed on 11 November 2020).

BBC News. 2021. COVID: Why Has Peru Been So Badly Hit? [Press Release]. Available online: https://www.bbc.com/news/worldlatin-america-53150808 (accessed on 11 June 2021).

BMJ. 2021. COVID-19: Peru's Official Death Toll Triples to Become the World's Highest BMJ [Press Release]. Available online: https:/ / www.bmj.com/content/373/bmj.n1442 (accessed on 11 June 2021).

Braga, Carlos, Leif Sjöblom, and Howard Yu. 2013. Emerging Markets Perspectives. IMD Real-World Learning. Available online: https: / / www.imd.org/contentassets / 0604e023b37a4193854b07a8fcb80c35/24.-emerging-markets-perspectives-27.06.13.pdf (accessed on 26 June 2021).

Bull, Greta. 2018. Financial Inclusion: Is the Glass Half Empty or Half Full? (Pt 2). Available online: https:/ /www.cgap.org/blog/ financial-inclusion-glass-half-empty-or-half-full-pt-2 (accessed on 3 January 2022).

Cámara, Noelia, and David Tuesta. 2014. Measuring Financial Inclusion: A Multidimensional Index: Working Paper. BBVA Research. Working Paper. Available online: https://www.bbvaresearch.com/wp-content/uploads/2014/09/WP14-26_FinancialInclusion2.pdf (accessed on 14 April 2021).

CGAP. 2011a. Global Standard-Setting Bodies and Financial Inclusion for the Poor: Proportionate Standards and Guidance. GPFIGlobal Partnership for Financial Inclusion. Available online: https:/ /www.cgap.org/sites/default/files/CGAP-White-PaperGlobal-Standard-Setting-Bodies-Oct-2011.pdf (accessed on 1 May 2021).

CGAP. 2011b. Marketing Branchless Banking: Examples from Around the World. [PowerPoint Slides]. Available online: https:/ / www.ifc.org/wps/wcm/connect/52fb5786-a45a-4caf-8b38-25a9a64a31a0/Tool\%2B3.7e.\%2BCGAP\%2BMarketing\% 2BBranchless\%2BBanking\%2B\%285.2011\%29.pdf?MOD=AJPERES\&CVID=jlzQM7O (accessed on 20 July 2021).

CGAP. n.d. Regulation for Inclusive Digital Finance. Available online: https:/ / www.cgap.org/topics/collections/regulation-inclusivedigital-finance (accessed on 3 January 2022).

Chatain, Pierre-Laurent, Andrew Zerzan, Wameek Noor, Najah Dannaoui, and Louis de Koker. 2013. Protecting Mobile Money against Financial Crimes. Available online: https:/ / elibrary.worldbank.org/doi/abs/10.1596/978-0-8213-8669-9 (accessed on 3 January 2022).

CIA.gov. 2021a. The World Factbook: Brazil. Available online: https://www.cia.gov/the-world-factbook/countries/brazil/ \#geography (accessed on 29 July 2021).

CIA.gov. 2021b. The World Factbook: Kenya. Available online: https://www.cia.gov/the-world-factbook/countries/kenya/ \#geography (accessed on 29 July 2021).

CIA.gov. 2021c. The World Factbook: Pakistan. Available online: https://www.cia.gov/the-world-factbook/countries/pakistan/ \#government (accessed on 29 July 2021).

CIA.gov. 2021d. The World Factbook: Peru. Available online: https://www.cia.gov/the-world-factbook/countries/peru/\#geography (accessed on 29 July 2021).

CIA.gov. 2021e. The World Factbook: Philippines. Available online: https://www.cia.gov/the-world-factbook/countries/philippines/ \#geography (accessed on 29 July 2021).

Claessens, Stijn. 2006. Access to Financial Services: A Review of the Issues and Public Policy Objectives. The World Bank Research Observer, Volume 21. Available online: https://www.researchgate.net/publication/5217978_Access_to_Financial_Services_A_ Review_of_the_Issues_and_Public_Policy_Objectives (accessed on 1 May 2021).

Dalberg. 2012. CGAP Landscape Study on International Remittances through Mobile Money: Final Report. CGAP. [PowerPoint Presentation]. Available online: https://www.gsma.com/mobilefordevelopment/wp-content/uploads/2012/06/20 12landscapestudyoninternationalremittancesthroughmobilemoney.pdf (accessed on 13 June 2021). 
Damodaran, Akhil. 2013. Financial Inclusion: Issues and Challenges. AKGEC International Journal of Technology 4: 54-59. Available online: https:/ /www.researchgate.net/publication/309194840_Financial_Inclusion_Issues_and_Challenges (accessed on 19 April 2021).

de Koker, Louis, Nicholas Morris, and Sue Jaffer. 2020. Regulating Financial Services in an Era of Technological Disruption. Available online: https:/ /journals.latrobe.edu.au/index.php/law-in-context/article/view/98/169 (accessed on 4 January 2022).

Demirgüç-Kunt, Asli, Leora Klapper, Dorothe Singer, Saniya Ansar, and Jake Hess. 2018. The Global Findex Database 2017: Measuring Financial Inclusion and the Fintech Revolution. World Bank. Available online: https://openknowledge.worldbank.org/ bitstream/handle/10986/29510/9781464812590.pdf (accessed on 25 June 2021).

Easypaisa. 2021a. About Us. Available online: https:/ / easypaisa.com.pk/about-easypaisa/\#about_us_sec (accessed on 29 July 2021).

Easypaisa. 2021b. Easypaisa Is a One-Stop-Shop for All Your Payment Needs: Products. Available online: https://easypaisa.com.pk/ products-promotions / (accessed on 29 July 2021).

Economist Intelligence Unit. 2019. Global Microscope 2019: The Enabling Environment for Financial Inclusion. Available online: https://www.google.com/url?sa=t\&rct=j\&q=\&esrc=s\&source=web\&cd=\&ved=2ahUKEwjLxorSz5zwAhWh_ rsIHVNsBM8QFjAGegQIBhAD\&url=https\%3A\%2F\%2Fidbinvest.org\%2Fen\%2Fdownload\%2F8783\&usg=AOvVaw17TjJmK2 _kkIqvGmccJoEb (accessed on 26 April 2021).

Economist Intelligence Unit. 2020. Global Microscope 2020: The Role of Financial Inclusion in the COVID-19 Response. Available online: https: / /idbinvest.org/en/download/11712 (accessed on 26 April 2021).

Gates, Bill. 2015. 2015 Annual Letter: A Big Bet for 2030. [Blog]. Available online: https:/ /www.gatesnotes.com/2015-annual-letter? page=3\&lang=en\&WT.mc_id=01_29_2015_AL2015-BG_FB_WorldBankingmap_Top_16\&fbclid=IwAR0S3n2DFTWPKthi641A9 3i66YJQsMKcoA0c6LWH1plLNeHQhL_pnjpvmFg (accessed on 20 July 2021).

Ghosh, Saibal. 2016. How Important Is Mobile Telephony for Economic Growth? Evidence from MENA Countries. Info 18: 58-79. [CrossRef]

GLOBE. 2014. 2014 Annual and Sustainability Report. Available online: https://www.globe.com.ph/content/dam/globe/brie/Aboutus/investor-relations / documents / Annual-and-Sustainability-Reports/GLO-2014-Annual-and-Sustainability-Report.pdf (accessed on 10 June 2021).

GLOBE. 2017. Integrated Report 2017. Available online: https://www.globe.com.ph/content/dam/globe/brie/About-us/investorrelations/documents/Annual-and-Sustainability-Reports/GLO-2017-Integrated-Report.pdf (accessed on 10 June 2021).

GLOBE. 2021. GCASH: Everything You Need to Know to Make Life Easier [Press Release]. Available online: https://www.globe.com. $\mathrm{ph} / \mathrm{go} /$ technology/article/gcash-everything-you-need-to-know.html\#gref (accessed on 28 July 2021).

GPFI SSBs Conference. 2021. Financial Inclusion-A Pathway to Financial Stability? Understanding the Linkages. Available online: https:/ / www.gpfi.org/publications/issues-paper-3-financial-inclusion-pathway-financial-stability-understanding-linkages (accessed on 3 January 2022).

Hasnain, Sophia, Abigail Komu, and Christopher Blackburn. 2016. Mobile Money in the Philippines: Market Conditions Drive Innovation with Smart Money and GCASH. GSMA Association. Available online: https://www.gsma.com/ mobilefordevelopment/programme/mobile-money/mobile-money-philippines-market-conditions-drive-innovation-smartmoney-gcash-philippines-becoming-mobile-money-innovation-hub/?utm_medium=social-media\&utm_campaign=mm23061 6\&utm_source=twitt (accessed on 23 June 2021).

International Finance Corporation. 2009. M-Money Channel Distribution Case-Kenya. Safaricom M-PESA. World Bank Group. Available online: https://www.ifc.org/wps/wcm/connect/e0d2a9bd-16b9-4a36-8498-0b2650b9af8b/Tool\%2B6.7.\%2BCase\% 2BStudy\%2B-\%2BM-PESA\%2BKenya\%2B.pdf?MOD=AJPERES\&CVID=jkCVy-n (accessed on 9 December 2020).

International Finance Corporation. 2011. Mobile Money Study 2011: Summary Report. Working Paper. Available online: https:/ / openknowledge.worldbank.org/bitstream/handle/10986/21743/947350WP0Box380eMoneyReport0Summary.pdf? sequence $=1 \&$ is Allowed $=y$ (accessed on 20 June 2021).

Jentzsch, Nicola. 2012. Implications of Mandatory Registration of Mobile Phone Users in Africa. DIW Discussion Papers, No. 1192. Berlin: Deutsches Institut für Wirtschaftsforschung (DIW).

Johnson, Burke, and Larry Christensen. 2004. Educational Research: Quantitative, Qualitative, and Mixed Approaches, 5th ed. Thousand Oakes: Sage.

Klapper, Leora, Annamaria Lusardi, and Peter Van Oudheusden. 2015. Financial Literacy Worldwide: Insights from the Standard \& Poor's Rating Services Global Financial Literacy Survey. International Bank for Reconstruction and Development \& World Bank. Available online: https:/ / gflec.org/wp-content/uploads/2015/11/3313-Finlit_Report_FINAL-5.11.16.pdf?x66755 (accessed on 28 July 2021).

Klapper, Leora, Saniya Ansar, Jake Hess, and Dorothe Singer. 2021. Financial Inclusion and Financial Regulation. Available online: https:/ / globalfindex.worldbank.org/sites/globalfindex/files/referpdf/FindexNote8_17.pdf (accessed on 3 January 2022).

Macedo, Carlos, Marcelo Cintra, Steven Goncalves, and Nelson Catala. 2017. Future of Finance: Fintech's Brazil Moment [Brazil's Over-Branched Banking System Is Ripe for Disruption by New Entrants]. Goldman Sachs. Available online: https://www. gspublishing.com/content/research/en/reports/2017/05/12/f21e671e-dad0-4ef4-ba07-d694211b0c94.pdf (accessed on 28 July 2021).

Malhotra, Naresh. 2010. Marketing Research: An Applied Orientation, 6th ed. Hoboken: Pearson/Prentice Hall. 
Mauree, V., and G. Kohli. 2013. The Mobile Money Revolution: Part 2: Financial Inclusion Enabler. ITU-T Technology Watch Report. Available online: https:/ / www.itu.int/dms_pub/itu-t/oth/23/01/T23010000200002PDFE.pdf (accessed on 16 May 2021).

McKay, Claudia, and Mark Pickens. 2010. Branchless Banking 2010: Who Is Served? At What Price? What Is? CGAP-Consultative Group to Assist the Poor. Focus Note. Available online: https://www.cgap.org/sites/default/files/researches/documents/ CGAP-Focus-Note-Branchless-Banking-2010-Who-Is-Served-At-What-Price-What-Is-Next-Sep-2010.pdf (accessed on 5 July 2021).

McKinsey Global Institute. 2018. Outperformers: High-Growth Emerging Economies and the Companies That Propel Them. McKinsey \& Company. Available online: https://www.mckinsey.com/ \{\}/media/mckinsey/industries/public\%20and\%20social\% 20sector/our\%20insights / outperformers\%20high\%20growth\%20emerging\%20economies\%20and\%20the \%20 companies \%20 that\%20propel\%20them/mgi-outperformers-in-brief-sep-2018.pdf (accessed on 26 July 2021).

Mithe, Alaze. 2015. Mobile Financial Services for Microfinance Institutions: A Case Study of Easypaisa and Tameer in Pakistan. IFC and Swiss Confederation. Available online: https://documents1.worldbank.org/curated/en/852401500461391376/pdf/117452 -WP-PK-Tool-11-3-Mobil-Finan-Serv-Tameer-in-Pakistan-1-29-15-Series-IFC-mobile-money-toolkit-PUBLIC.pdf (accessed on 29 July 2021).

Moreno, Sandra, Madhu Vazirani, and Steven Lillis. 2015. Billion Reasons to Bank Inclusively. Accenture Banking. Available online: https://www.accenture.com/us-en/_acnmedia/Accenture/Conversion-Assets/DotCom/Documents/Global/PDF/ Dualpub_22/Accenture-billion-reasons-bank-inclusively.pdf (accessed on 16 April 2021).

Ngugi, Benjamin, Mathew Pelowski, and Javier Gordon Ogembo. 2010. M-PESA: A case study of the critical early adopters' role in the rapid adoption of mobile money banking in Kenya. The Electronic Journal of Information Systems in Developing Countries 43: 1-16. Available online: https:/ / doi.org/10.1002/j.1681-4835.2010.tb00307.x (accessed on 16 May 2021). [CrossRef]

Nguyen, Thi Truc Huong. 2020. Measuring Financial Inclusion: A Composite Index for the Developing Countries. Journal of Economics and Development 23: 77-99. [CrossRef]

Nubank. 2021. Homepage. Available online: https://nubank.com.br/en/ (accessed on 1 July 2021).

Omar, Mohamed Abdullah, and Kazuo Inaba. 2020. Does financial inclusion reduce poverty and income inequality in developing countries? A panel data analysis. Journal of Economic Structures 9: 1-25. [CrossRef]

Pearce, Douglas, and Claudia Ruiz Ortega. 2012. Financial Inclusion Strategies: Reference Framework (English). World Bank Group. Working Paper. Available online: http://documents1.worldbank.org/curated/en/801151468152092070/pdf/787610WP0P14450 Ouse0only0900A9RD899.pdf (accessed on 1 June 2021).

Pinar Ardic, Oya, Maximilien Heiman, and Nataliya Mylenko. 2011. A Cross-Country Analysis with a New Data Set Can Access Financial Services Worldwide and the Financial Inclusion Agenda-The World Bank. Working Paper. Available online: https:/ / www.cgap.org/sites/default/files/CGAP-Access-to-Financial-Services-and-the-Financial-Inclusion-Agendaaround-the-World-Jan-2011.pdf (accessed on 11 April 2021).

Rojas-Suarez, Liliana, and Veronica Gonzales. 2010. Access to Financial Services in Emerging Powers: Facts, Obstacles, and Policy Implications. OECD. Background Paper. Available online: https://www.oecd.org/dev/pgd/45965165.pdf (accessed on 22 April 2021).

S\&P Global Market Intelligence. 2020. Financial Inclusion Would Have Helped Contain Coronavirus, BCP Manager Says [Press Release]. Available online: https://www.spglobal.com/marketintelligence/en/news-insights/latest-news-headlines/financialinclusion-would-have-helped-contain-coronavirus-bcp-manager-says-60808067 (accessed on 20 October 2020).

Safaricom PLC. 2020. Annual Report 2020. Available online: https://www.safaricom.co.ke/images/Downloads/Safaricom_AR2020_ bookmarked_ONLINE_29_07_2020.pdf (accessed on 20 June 2021).

Safaricom PLC. 2021. Annual Report and Financial Statements 2021. Available online: https://www.safaricom.co.ke/images/ Downloads/2021_Annual_Report_Single_Spread_Final.pdf (accessed on 28 June 2021).

Safaricom. 2011. Group Annual Report \& Accounts. Available online: https://www.safaricom.co.ke/images/Downloads / Annual_ Reports/2011_Annual_Report_FINAL.pdf (accessed on 8 June 2021).

Safaricom. 2014. Annual Report 2014. Available online: https://www.safaricom.co.ke/images/Downloads/Resources_Downloads/ annual_report-2014.pdf (accessed on 10 June 2021).

Safaricom. 2017. Safaricom Annual Report and Financial Statements 2017. Available online: https://www.safaricom.co.ke/images/ Downloads/Resources_Downloads/Safaricom_2017_Annual_Report.pdf (accessed on 12 June 2021).

Safaricom. 2021. M-PESA Rates. Available online: https://www.safaricom.co.ke/personal/m-pesa/getting-started/m-pesa-rates (accessed on 15 June 2021).

Scharwatt, Claire, Arunjay Katakam, Jennifer Frydrych, Alix Murphy, and Nika Naghavi. 2014. State of the Industry: Mobile Financial Services for the Unbanked. GSMA's Mobile Money for the Unbanked (MMU). Available online: https://www.gsma.com/ mobilefordevelopment/wp-content/uploads/2015/03/SOTIR_2014.pdf (accessed on 30 April 2021).

Sirota, Fabio, and Gustavo Fratini. 2018. A Case about Nubank: The Story of an Innovative Fintech in Brazil. Master's thesis, Politecnico di Milano, Milano, Italy. Available online: https://www.politesi.polimi.it/bitstream/10589/149606/1/Final\%20Thesis.pdf (accessed on 10 July 2020).

Sotomayor, Narda, Jacqueline Talledo, and Sara Wong. 2018. Determinants of Financial Inclusion in Peru: Recent Evidence from the Demand Side. Superintendencia de Banca y Seguros. SBS Working Paper. Available online: https://www.sbs.gob.pe/Portals/0/ jer/DDT_ANO2018/DT-001-2018\%20(eng).pdf (accessed on 19 July 2021). 
Statista. 2021. Number of Customers of Fintech Company Nubank in Brazil from 2016 to 2021 (in Millions). Available online: https:/ / www.statista.com/statistics/882274/brazil-number-customers-nubank/ (accessed on 29 July 2021).

Stein, Peer, Bikki Randhawa, and Nina Bilandzic. 2011. Toward Universal Access: Addressing the Global Challenge of Financial Inclusion. International Finance Corporation and World Bank. Working Paper. Available online: https://www.gpfi.org/sites/ gpfi/files/documents/Toward\%20Universal\%20Access_0.pdf (accessed on 22 April 2021).

Telenor Microfinance Bank. 2017. 2017 Annual Report. Available online: https://telenorbank.pk/wp-content/uploads/2020/03/ Annual_report_web_2017.pdf (accessed on 14 July 2021).

The Guardian. 2021. Peru Has the World's Worst per Capita COVID Toll after Death Data Revised [Press Release]. Lima. Available online: https: / www.theguardian.com/world/2021/jun/01/peru-has-worlds-worst-per-capita-covid-toll-after-death-datarevised (accessed on 11 June 2021).

The World Justice Project. 2020. Rule of Law Index. Available online: https://worldjusticeproject.org/rule-of-law-index/global/2020 (accessed on 28 June 2021).

UNCDF. n.d. Financial Inclusion and the SDGs. Available online: https:/ / www.uncdf.org/financial-inclusion-and-the-sdgs (accessed on 3 January 2022).

United Nations-UNSGSA. 2010. Annual Report to the Secretary-General. Available online: https://www.unsgsa.org/sites/default/ files/resources-files/2020-09/UNSGSA_AR.pdf (accessed on 1 May 2021).

United Nations-UNSGSA. 2017. Financial Inclusion Transforming Lives: Annual Report to the Secretary-General. United Nations Secretary-General's Special Advocate for Inclusive Finance Development (UNSGSA). Available online: https: //responsiblefinanceforum.org/wp-content/uploads/2017/10/UNSGSA_report_2017-final.pdf (accessed on 15 May 2021).

Wishart, Neville. 2006. Micro-Payment Systems and Their Application to Mobile Networks. World Bank Group. Working Paper. Available online: https:/ / documents1.worldbank.org/curated/en/886371468160779311/pdf/352950infoDev1m1Commerce0 1PUBLIC1.pdf (accessed on 15 July 2021).

World Bank. 2016. Brazil—Systematic Country Diagnostic. World Bank. Available online: https://documents.worldbank.org/en/ publication/documents-reports / documentdetail/239741467991959045/brazil-systematic-country-diagnostic-retaking-thepath-to-inclusion-growth-and-sustainability (accessed on 1 August 2021).

World Bank. 2020a. Employment to Population Ratio, 15+, Total (\%) (Modeled ILO Estimate)—Peru, Kenya, Philippines, Pakistan, Brazil. Available online: https:/ / data.worldbank.org/indicator/SL.EMP.TOTL.SP.ZS?end=2020\&locations=PE-KE-PH-PK-BR\& start=2010 (accessed on 28 July 2021).

World Bank. 2020b. Islamic Republic of Pakistan: Leveling the Playing Field: Systematic Country Diagnostic. World Bank. Available online: https://openknowledge.worldbank.org/bitstream/handle/10986/34549/Pakistan-Systematic-Country-DiagnosticLeveling-the-Playing-Field.pdf?sequence=4\&isAllowed=y (accessed on 3 August 2021).

World Bank. 2020c. Kenya-Systematic Country Diagnostic. World Bank. Available online: https://documents.worldbank.org/ en/publication/documents-reports/documentdetail/919181490109288624/peru-systematic-country-diagnostic (accessed on 4 August 2021).

World Bank. 2020d. Population Ages 15-64, Total—Peru, Kenya, Brazil, Philippines, Pakistan. Available online: https://data worldbank.org/indicator/SP.POP.1564.TO?end=2020\&locations=PE-KE-BR-PH-PK\&start=2006 (accessed on 29 July 2021).

World Bank. 2021a. Overview of the Philippines. World Bank. Available online: https://www.worldbank.org/en/country/ philippines/overview (accessed on 6 August 2021).

World Bank. 2021b. The World Bank in Peru. Available online: https://www.worldbank.org/en/country/peru/overview (accessed on 7 August 2021).

The World Bank. 2021. Regulations Help Explain Variations in Financial Inclusion. Available online: https:/ /blogs.worldbank.org/ allaboutfinance/regulations-help-explain-variations-financial-inclusion (accessed on 3 January 2022). 